\title{
History of the Virginia Oyster Fishery, Chesapeake Bay, USA
}

\author{
David M. Schulte* \\ Department of Fisheries, College of William and Mary, Virginia Institute of Marine Science, Gloucester, VA, USA
}

Oyster populations in Virginia's waters of Chesapeake Bay were lightly exploited until the early 1800s, when industrial fishery vessels first arrived, driven south from New England due to the collapse of northeastern oyster fisheries. Early signs of overexploitation and habitat degradation were evident by the 1850s. The public fishery, where oyster fishers harvest on state-owned bottom, rapidly developed after the Civil War and peaked in the early 1880s. Declines were noted by the late 1880s and eventually prompted the creation of Virginia's shell-planting and oyster-seed (young-of-the-year, YOY) moving repletion program in the 1920s. Despite management and increasing repletion efforts, the public fishery collapsed (annual landings $<10 \%$ of peak historical landings) by the early 1960 s. The private leasehold fishery, in which individuals rent areas outside the public grounds to plant shells and oysters for their own private use, surpassed the public fishery by the late 1920s, which partly masked this decline due to overfishing, habitat degradation, and diseases until both public and private fisheries completely collapsed in the mid-1980s

OPEN ACCESS

Edited by:

Maria Lourdes D. Palomares, FishBase Information and Research Group, Philippines

Reviewed by:

Fabian Zimmermann, Norwegian Institute of Marine Research, Norway

Andrés M. Cisneros-Montemayor, University of British Columbia, Canada

*Correspondence: David M. Schulte david.m.schulte@usace.army.mil

Specialty section:

This article was submitted to Marine Fisheries, Aquaculture and Living Resources,

a section of the journal Frontiers in Marine Science

Received: 20 December 2016 Accepted: 18 April 2017 Published: 09 May 2017

Citation:

Schulte DM (2017) History of the Virginia Oyster Fishery, Chesapeake Bay, USA. Front. Mar. Sci. 4:127. doi: 10.3389/fmars.2017.00127 after a third disease outbreak. This disease outbreak was likely related to warming waters. Overfishing and concomitant habitat loss followed a pattern of sequential population collapses observed in wild oyster fisheries along the Coastlines of the United States and worldwide. In recent years, expanding hatchery-produced seed oysters and aquaculture significantly increased leasehold landings. The wild fishery has also increased as disease resistance is developing naturally in the wild stocks, but remains $\sim 5 \%$ of peak landings. Improved management has assisted in this recent limited recovery, improving these efforts further by enhancing stock recovery via large no-take sanctuaries, among other actions, could assist in stock recovery.

Keywords: oyster, history, fishery, Chesapeake Bay, virginia, Crassostrea virginica

\section{BACKGROUND OF THE FISHERY AND MANAGEMENT FROM PRE-COLONIAL TO PRESENT}

\section{Early Fishing (Pre-1600)}

Native Americans settled in the Chesapeake Bay region, 9500 years BCE, during the glacial retreat when the Chesapeake Bay as we would recognize it today began to form (Hobbs, 2004). Oysters colonized the Bay $\sim 6500$ years BCE as salt water from the Atlantic Ocean, driven by glacial melting, penetrated up-bay, and up-river (Bratton et al., 2003). Reefs grew in elevation and area while expanding upriver(s) and northward as salinity suitable to their survival increased in extent (McCormick-Ray, 1998, 2005; Hargis and Haven, 1999; Smith et al., 2003; Hobbs, 2004).

Native Americans prior to European colonization were few in number relative to the human population living in the Bay watershed today. Estimates of artisanal-level annual harvests from this time period cannot be made. Where Native American settlements were near waters that contained oyster reefs, shell middens consisting of oyster, mussel, and clam shells can often be found. Some 
middens are sizeable, such as one along the shores of Pope's Creek, Virginia, which covers 12.1 ha (Wennersten, 1981) several meters deep, indicating hundreds to thousands of years of harvesting. At some middens, oyster shells decreased in average size over time, indicating that the Native Americans' sequential harvesting of oysters could have negative impacts on the sizefrequency distributions of oysters (Kent, 1988; Jagani, 2011), as observed in middens of other mollusk species (de Boer et al., 2000), though no wide scale decline in size has been observed in the Bay (Rick et al., 2016).

\section{European Colonization and the Early Oyster Fishery (1600s-Early 1864)}

The first European settlers colonized Virginia in the early 1600s on the northern bank of the lower James River, the largest Virginia River, located near the confluence of the Bay and Atlantic Ocean (Figure 1). Settlers at first collected oyster by hand and/or using primitive tools from shallow, nearshore reefs for food (Tyndall, 1608), similar to Native Americans. Archeological data of colonial middens at Jamestown revealed that a mix of local oysters as well as oysters from the mouth of the James River had been collected for food, indicating local populations may have been depleted by colonists (Harding et al., 2008). The use of oyster shells for lime ( $\mathrm{CaO}$, used in agriculture and construction mortar) began in the mid-1600s and became more extensive (Bailey, 1938) as the colonial era in Virginia progressed. There are records of reefs in the James River providing shell for lime, with White Shoal, a reef that remains part of the public fishery today, mentioned as early as 1638; Native Americans middens were also used as a good source of shells. Using shells for lime production continued throughout

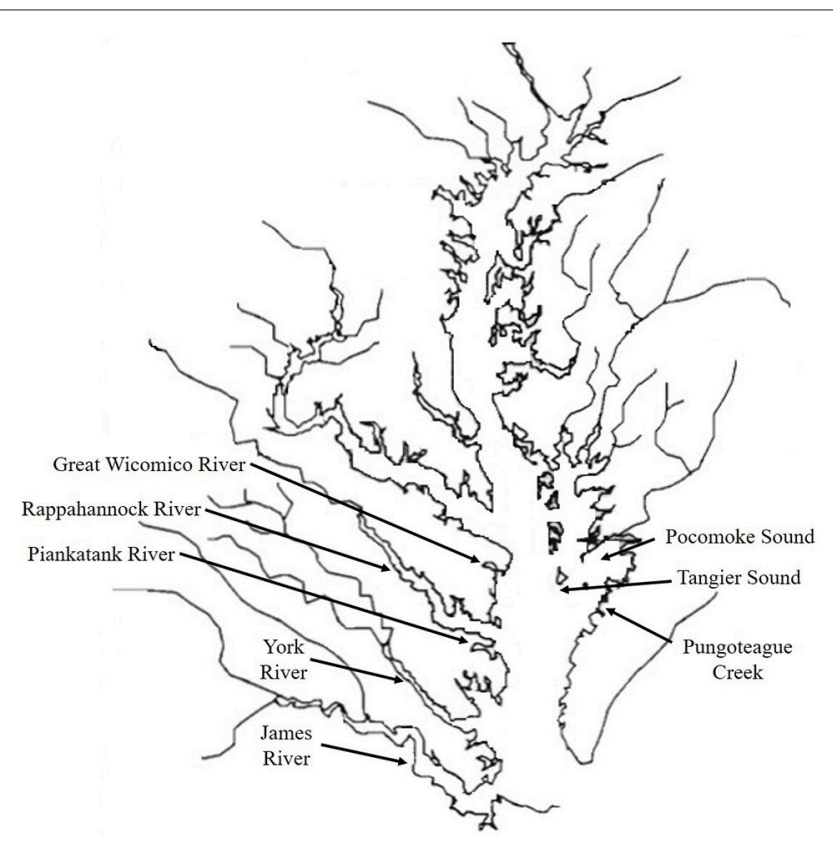

FIGURE 1 | Overview of Chesapeake Bay, key Virginia oyster fishery locations indicated. the colonial period (Ford, 1891). Oyster shells, once shucked of meat, were used in Virginia for road beds, agricultural lime, chicken "grit" (a poultry feed supplement), mortar, a composite form of concrete made of lime, sand, and crushed oyster shells called "tabby," and starting in the mid-1800s, railroad ballast (Hargis and Haven, 1999). Impacts to oyster reefs by early settlers appear to have been limited and local during the seventeenth and eighteenth centuries.

The first large-scale commercial fishing was by New England oyster fishers that sailed south to the Chesapeake Bay and began dredging subtidal reefs for oysters in the early 1800 s after depletion of their own beds (Kirby, 2004). Dredging continued for several years and the total harvest and dredge-related damage (Winslow, 1881, 1882; Lenihan and Peterson, 1998, 2004) to what had been undisturbed sub-tidal oyster reefs is unknown. Dredging was made illegal in Virginia in 1810, at which time the New England dredgers simply sailed further north into Maryland waters until they were banned there in 1820 . These bans did not entirely prevent dredging, due to lack of an organized marine police at the time, as it was noted that New Englanders were occasionally seen as late as the mid-1800s poaching oysters from reefs near the mouth of the James River (Paxton, 1858). Dredging for oysters would remain illegal for decades in Virginia and only hand tongs, a simple tool consisting of two long-handled, hinged, metal-toothed rakes developed in the late 1700s, were permitted.

In the 1850s, the Virginia oyster fishery expanded rapidly (U.S Census, 1850, 1860; De Bow, 1858), concomitant with rail lines that began to link centers of commerce throughout the USA. Harvests increased (Figure 2) from 178,000 bushels in 1849 to 2.3 million bushels in 1859 ( 1 bushel $=0.049225$ $\mathrm{m}^{3}$ ) (Auditor of Public Accounts, 1776-1928; U.S Census, 1850, 1860). Testimony (Paxton, 1858) suggests that this increase in harvests occurred at a rapid pace: "The oyster trade may be said to have sprung into existence in the last 10 years. Ten years ago, but few persons living away from tidewater ever used oysters. Now the country has been penetrated in every direction by railways, and at this time oysters taken from our Virginia waters are probably used more extensively in the towns and villages of the far West, than they were a few years since in Virginia within fifty miles of tidewater." This increase appears primarily due to growing regional, demand, enabled by more effective means of shipping and preservation. The first largescale commercial canning operation for oysters, which allowed for shipping oyster meat throughout the USA, began in Baltimore in 1844 (Jarvis, 1988), which would soon become the center of oyster canning in Chesapeake Bay (Maryland Bureau of Statistics and Information, 1903) ${ }^{1}$. By 1858, about 4 million bushels of oysters were being canned annually in Baltimore (Paxton, 1858), the majority processed being fished from Maryland waters though Virginia oysters were also canned here. Small shipments of Virginia oysters to various ports along the North East coast occurred, early records indicate $\sim 100,000$ bushels were being shipped annually during 1846-1857 to Boston, though much

\footnotetext{
${ }^{1}$ https://www.google.com/search?biw=1167\&bih=415\&tbm=bks\&q=inauthor: $\% 22$ Maryland.+Bureau+of+Statistics+and+Information\%22\&sa=X\&ved= 0ahUKEwjZ38uTwsDTAhVI3mMKHUrzC34Q9AgISTAG
} 


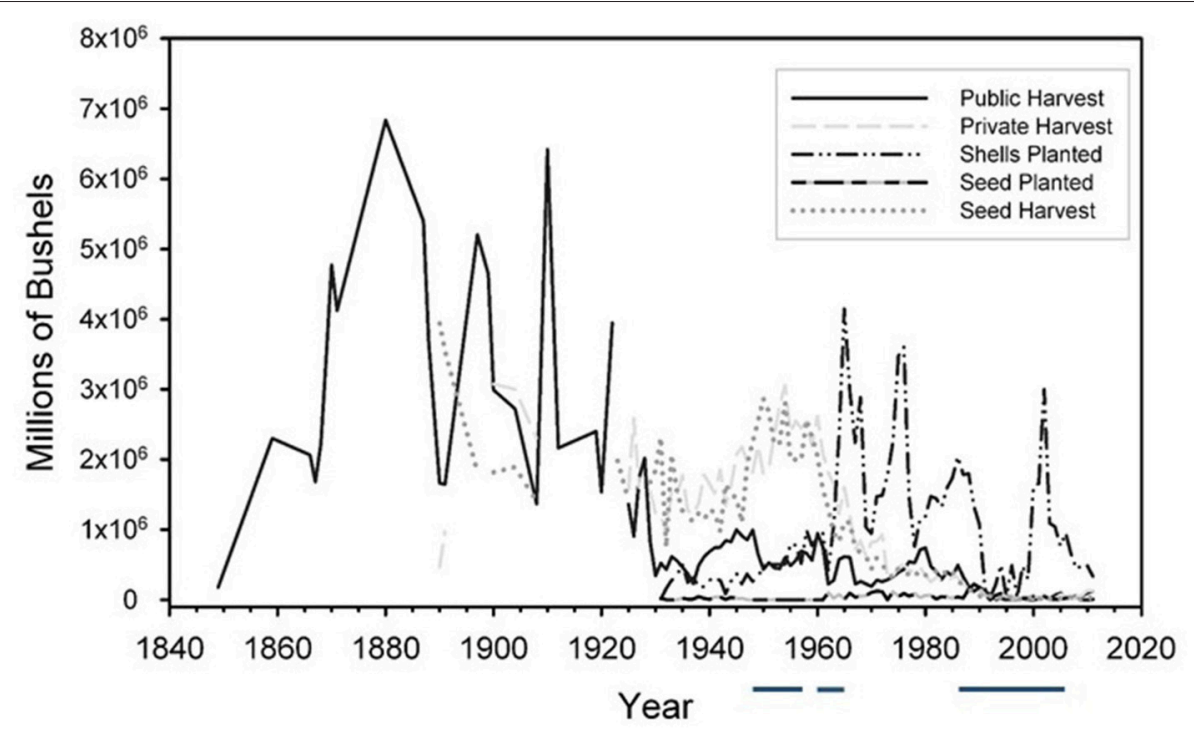

FIGURE 2 | History of the oyster fishery, showing public, private, and seed harvests with repletion activity (shell and seed plants) over time. Data for repletion 2003-14 are based on estimates from VMRC annual work plans. 1 bushel $=0.049225 \mathrm{~m}^{3}$. Blue lines are years of disease epidemics, first line is the first Dermo epidemic peak years, second line are the peak years of the MSX epidemic, third line is the second Dermo epidemic peak years.

smaller shipments had occurred previously, beginning in 1826, to Boston and other northern cities, including New York City. Smaller and younger sub-market sized $(\leq 76 \mathrm{~mm})$, often YOY (young-of-the-year) oysters, called "seed" were also harvested and sold, primarily to Northern States, for planting and grow out to market size. Records indicate seed oysters from Virginia waters were being shipped as far North as Connecticut as early as 1830 (Goode, 1887) and even overseas (De Broca, 1865). It is unknown how large this seed fishery was, though it may have been comparable in size to the market oyster fishery by the 1850 s.

With the advent of the Civil War in 1861, a naval blockade was placed in Virginia waters. Harvests in Virginia declined as local fishermen were often unable to fish during the war (18611865). Oyster prices tripled in cities such as Alexandria, Virginia, due to lack of supply (The Alexandria Gazette, 1963-1964). The magnitude of the decline in oyster harvests due to the Civil War remains unclear; the only reliable comparison was between the 1859 harvest of 2.3 million bushels and the first post-war harvest in 1965 at 2 million bushels (Figure 2). One source (Brown, 1872) indicates that the harvest during the Civil War may have increased due to harvest by northern dredgers, who, upon payment of a permit fee, were able to dredge Virginia oyster grounds while being protected by the Northern Navy. Virginian watermen could also harvest upon payment of a fee, though few did as many were at war or lacked the money to pay. These dredging activities ceased after the War.

\section{Major Peak of the Virginia Oyster Fishery 1865-1890}

In 1860 county courts were authorized to appoint inspectors of oysters to enforce oyster laws, which were first implemented in 1866. A harvesting season for oysters was established, with oyster fishing prohibited during the months of June-August and limited during May and September to no more than 25 bushels/man/day. During other months, there were no harvest limits. Various license fees and taxes were also established for oyster harvesters and related processing activities. There was a rapid expansion of the fishery from 1865 to 1871, which doubled from 2 to 4 million bushels/year (Virginia Auditor of Public Accounts, 1776-1928). The bushel tax was repealed in less than a decade, so records of harvests became intermittent until the 1926-1927 harvest season when a bushel tax on harvested oysters was reinstated Commission of Fisheries of Virginia (1907-1967).

There were two other significant changes in law during this era. One was the codification of the private leasehold system, providing legal protection to "planters" who had been active for some time on a small scale, but who had little legal recourse from pirating fishers tonging their plantings. These leaseholders rented plots that they were given rights of ownership, upon which to plant shells and seed for their own private benefit, permits were granted by oyster inspectors who worked for the State. The second was the permitting of dredges but limiting them to waters over $6.1 \mathrm{~m}$ deep. Dredgers worked deeper, sometimes unexplored waters, discovering, and exploiting the last pristine oyster reefs of Tangier and Pocomoke Sounds in the mid-Bay region near the Maryland border in the 1870s. A survey of oyster reefs in the Tangier and Pocomoke Sound region (Winslow, 1882), describes the appearance of such reefs as follows: "These reefs consisted of long, narrow oysters...no single oysters of any (age) class, but all grew in clusters of 3-15. The shells were clean and white, free from mud and sand. The mature oysters were covered and the interstices between them filled with younger oysters," similar to the account made of shallower, unexploited reefs: "In some banks their crowded condition may be inferred from the fact that I counted as many as 40 (live adult) Oysters in an area included by a quadrangle of wire including exactly one square foot $\left(0.0929 \mathrm{~m}^{2}\right) ; 30$ individuals to the square 
foot was a fair average on one bank examined (Ryder, 1884)." Undisturbed oyster reefs appear to have had up to 320 adult oysters $/ \mathrm{m}^{2}$ of varying sizes up to $23 \mathrm{~cm}$ (adults are classed as oysters $\geq 35 \mathrm{~mm}$ ), perhaps larger, and growing in dense, cohesive aggregations that induced an elongate growth form. This elongated architecture of oysters in dense aggregations was a response to competition for space and food, and is similar to adaptations of rain forest trees that compete similarly for light (Poorter et al., 2003).

Little additional change occurred in the laws governing the fishery until the outlawing of dredging of oysters on any public oyster grounds in 1879. Virginia also eliminated its marine police force (created in 1875) due to a perceived lack of need of it, which resulted in pitched battles in many Virginia waters. In the Rappahannock River, dredging boats began to illegally harvest oysters openly during the winter of 1879-1880, using rifle and cannon fire to discourage local hand tong fishermen from fishing (Bulletin of the US Fish Commission, 1880). The marine police force was quickly re-instated to restore order and restore the ability of the state to collect taxes and fees related to the oyster fishery, which had dropped precipitously from $\$ 28,169$ USD in 1871 ( $\$ 501,770$ in 2013 USD) to a mere $\$ 541$ USD in 1879 (10,373 in 2013 USD). Illegal harvest by dredgers was estimated to be as high as 2 million bushels/year when the marine police patrol was disbanded (Moore, 1982). Conflicts between Maryland and Virginia oyster fishermen were also commonplace, especially in disputed waters of Tangier and Pocomoke Sounds and the Potomac River; these conflicts were the "Oyster Wars" of Chesapeake Bay (Wennersten, 1981) which at times grew intense enough to force the Governor of Virginia (William Cameron 1882-1885) to intercede (Moore, 1982; Tice, 1982). Oyster harvests peaked in the Chesapeake Bay during this era in 1880 at 6.3 million bushels of market oysters and 1.9 million bushels of "seed" oysters. Harvests remained high at over 5 million bushels/year until the late 1880s, when the first declines were observed. At this time (1890) total harvest was split into public and private ground harvest (Figure 2). Seed oysters were mostly planted ( $\sim 1.4$ million bushels) in state on private leased grounds. Seed during the great majority of the productive years of the private leasehold fishery came primarily from what came to be known as "seed beds" in the lower-salinity reaches of the James River. This was a region of high oyster recruitment due to favorable local hydrodynamics coupled with a slow growth rate due to the low salinity. This situation created a desire to move these oysters to enhance production coupled with lots of young oysters available to move and fairly steady rates of replacement, perfect for leaseholders. These reefs also consisted of thick deposits of shells, rising several meters off the bottom which could be harvested for many years before being reduced to footprints ( $\sim 12$ ha out of over 1,000 still have limited relief from the bottom even today) (Woods et al., 2005). The remainder, over 500,000 bushels, was shipped north where it was planted in New York, Rhode Island, and Connecticut waters, sustaining limited output in fisheries that had collapsed due to overharvest and environmental degradation (Kirby, 2004). Later shipments were smaller, being 100,000-150,000 bushels by 1930 and declining thereafter until it virtually ceased in
1950 when legislation was passed that forbid shipment of seed oysters outside the state unless seed demands of in-state oyster planters were met. Due to these demands, shipments of Virginia oyster seed to out-of-state planters became intermittent and quite small (50,000-100,000 bushels/year) (Report of the Commission of Fisheries of Virginia, 1907-1967; Alford, 1973; Mackenzie, 1996).

\section{Varying Fishery Output Years 1887-1912}

The first mention of public oyster ground depletion was by Paxton (1858), whose interviews of prominent members of the oyster industry and resulting testimony supported the first legislative attempts to govern the oyster fishery. He described depletion of oyster grounds in the York River and at the Hampton Bars in the lower Bay near the Atlantic Ocean confluence, which had been severely depleted and damaged by oyster dredging by the 1850s. Additionally, large oyster grounds abutting Craney Island, which lies at the confluence of the James and Elizabeth Rivers, had been depleted. Similar damage was noted along the Bayside of Virginia's Eastern Shore region, in addition to the depletion of large oyster beds in the Tangier/Pocomoke Sound region. Oyster rock was, at the time, found as far South as Cherrystone Creek near the mouth of the Bay but were so depleted prior to the first official maps of the public oyster grounds (Battle, 1892; Baylor, 1894, 1895) that the Cherrystone Creek oyster rocks were not included.

The next warning was by Winslow (1882) during his survey of oyster grounds in the James River and the Tangier/Pocomoke Sound region of Virginia in the late 1870 s. He noted that market sized oysters were in far lower numbers than expected, finding "one market sized oyster per three square yards of oyster reef, on average." At the time, Winslow noted that failure to enforce oyster cull laws, which returned smaller than market sized oysters and loose shell to the reefs was depleting the oyster beds. These early warnings for Virginia, similar to those being given in Maryland by scientists (Brooks, 1891), went unheeded. It is also during this time that seed oyster harvest peaked at over 3 million bushels/year in the 1890-91 and 1891-92 seasons.

The first significant declines occurred in the late $1880 \mathrm{~s}$ as harvests of market oysters dropped by several million bushels/year, from the peak of over 6 million bushels in 1879 and 1880 to less than 4 million by 1889 . By the 1890 s harvests of market oysters declined to less than 2 million bushels/year from the public grounds and the private planters were contributing much more to the overall harvest, which increased in acreage from $\sim 8,000$ ha in 1894 to over 24,000 ha by 1904 . Private leasehold harvests also increased, from $\sim 0.5$ million bushels in 1890 to almost 3 million bushels in 1904. Thus, what should have been viewed as a significant decline in public ground harvest (over 50\% in less than 25 years) was, outside of fishery managers occasionally raising an alarm (Report of the Board of Fisheries to the Governor of Virginia, 1900-1907), unnoticed. Private leaseholds continue to expand, peaking at over 52,000 ha by 1960 (Report of the Commission of Fisheries of Virginia, 1907-1967). The private leasehold fishery essentially masked the decline in public ground harvests as it surpassed them in the early 1900s. This would remain the typical condition 
of the fishery, a smaller public and larger private component, until the final decline and collapse of the fishery in the 1980s (Haven et al., 1978; Virginia Marine Resources Commission, 1985-88; Hargis and Haven, 1999; Kellum, 2008). Maryland's, has a small private leasehold fishery due to political interference by watermen (Kennedy and Breisch, 1983), public harvest have always exceeded private harvests in northern Chesapeake Bay. The private leasehold fishery was entirely (and to a significant degree still is) dependent on wild oyster seed (Haven et al., 1978; Bosch and Shabman, 1989), with a significant positive correlation between the two evident from the time series. The main weakness in this system was its reliance on wild oyster seed. The leasehold system was for most of its history essentially a livestock "finishing" operation where young oysters are moved from wild reefs to privately owned grounds for fattening for market. The relationship between harvested seed and private leasehold production was positive, with a 1-year lag observable between seed harvest and subsequent harvest from the private leaseholds on which it was planted. Seed oysters typically take an additional year to reach market size. Our analysis considered 1-, 2-, and 3-year lags between seed harvest and private lease harvest, with the 1 -year lag providing the best fit $\left(r^{2}=0.85\right.$, Figure 3). This is in agreement with a study done at the time (Report of the Virginia Fisheries Laboratory, 1953) that indicated maximum yield of planted oysters was obtained 15 months postplanting. Today, this system of planting and growing young oysters on shelled leased ground is still extensively used, though more modern aquaculture practices are being rapidly adopted by leaseholders with significant success (Murray and Hudson, 2011).

The wild fishery experienced a partial recovery after the early 1890s, when harvest on the public grounds increased from 1.6 million bushels/year to nearly 3 million bushels/year from 1900 to 1904 (Report of the Board of Fisheries to the Governor of Virginia, 1900-1907; McHugh and Bailey, 1957). The total oyster harvest of 1904 (7.6 million bushels) nearly equaled the peak of 1880 (Report of the Board of Fisheries to the Governor of Virginia, 1900-1907).

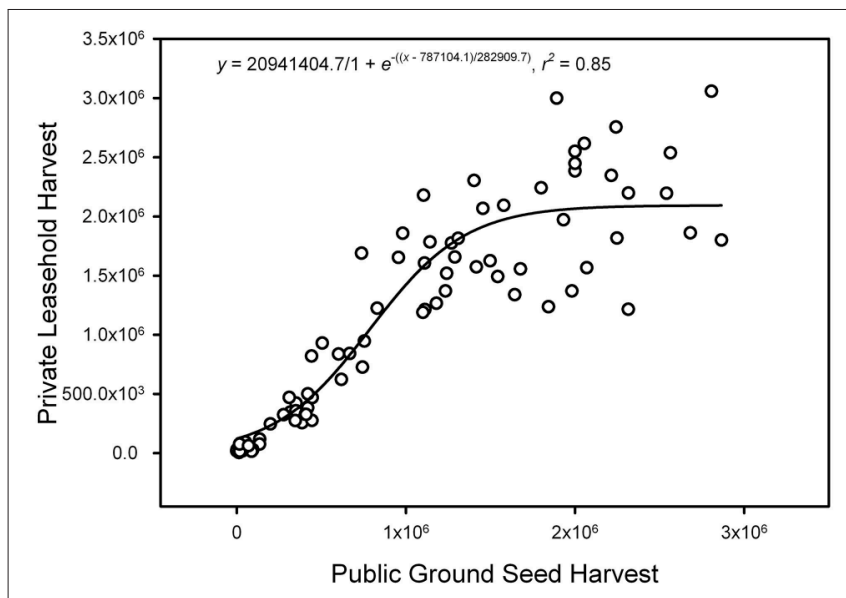

FIGURE 3 | Sigmoid fit of public ground seed oyster harvest to private leasehold harvest (units are VA bushels). 1 bushel $=0.049225 \mathrm{~m}^{3}$.
Harvests soon declined again, though unlike prior ones this decline appeared to be driven by changes in the market rather than a decline in fishery potential output, which suggests market factors at this time played a significant role in oyster harvest declines (Mackenzie, 1996, 2007). Consumers were concerned about illness due to oyster consumption. This was known in the oyster industry as the "Pure food" scare, which peaked during the 1907-1909 seasons and significantly reduced demand (McHugh and Bailey, 1957). This scare was caused by outbreaks of typhoid fever and other illnesses, some of which were linked to the oyster industry, and resulted in the Pure Food Laws of 1906. These linkages had merit; for example, the U.S. Surgeon General documented that raw sewage was being dumped immediately adjacent to oyster growing beds in Hampton, Virginia, and in Chincoteague, which is part of the Seaside Eastern Shore of Virginia and was, at the time, an important oyster producing area. These oysters were being sold for human consumption (Annual Report of the Surgeon General of the Public Health Service, 1915), some raw in the half-shell. The VA fish commission observed: "as a result of the "panic" and pollution scare in 1906 a large proportion (at least 50\%) of VA oyster carried over (left unharvested) on the beds." The Commission also noted that oysters were making the transition in consumption from a staple to a "semi-luxury" food item at this time (Report of the Board of Fisheries to the Governor of Virginia, 1900-1907). The temporary decline in demand caused several laws to be passed in 1908 in Virginia, to restore public confidence (Report of the Commission of Fisheries of Virginia, 1908-1912). Oyster and clam harvesting was prohibited from polluted waters from May 1st to August 15th and required that shellfish harvested in season were to be placed for at least 7 days in waters certified as unpolluted prior to be offered for sale as food. This process of relaying oysters subject from contaminated to clean water, called depuration, allows oysters to purge many contaminants, biological and others, from their tissues given sufficient time (Gardinali et al., 2004; Reboucas do Amaral et al., 2005; Nappier et al., 2008). However, demand for oysters increased in the 19091910 season, as the effects of the "panic" wore off and the largest harvest recorded since 1904 was seen, indicating stocks may have recovered during the years of lower demand. The oyster industry was operating at near full capacity by 1910 . This is the only instance, other than during World War 1, where there is evidence of market forces significantly depressing the Virginia oyster harvest. Stock declines, concomitant overharvesting and related habitat damage due to harvesting were the primary driver for the decrease in local landings (Hargis and Haven, 1999; Kirby, 2004), as imports of oyster meats and production in other areas of the country rose as harvests in Chesapeake declined. Additionally, locally, prices for oysters rose as harvests have declined, indicating demand has been higher than supply since at least 1970 (National Academy of Sciences, 2004) as well as the fact that Virginia oyster processors had begun importing gulf oysters since shortly after the MSX epidemic began (Murray and Kirkley, 2010), which formed the bulk of the oyster shucking done in Virginia for decades until the Deep Horizon oil spill of 2010.

The "cull law" of 1910 was a measure implemented to maintain the condition of the natural oyster habitat. Oystermen 
were to cull their catch over the reef from which it was taken and were legally permitted to keep only those oysters exceeding $76 \mathrm{~mm}$ in shell length; all other materials, including shells and undersize oysters, were to be returned to the reef. The exception to this rule was the "seed beds" of the James River, which supplied most of the "seed" oysters used by oyster planters throughout the state. Harvests remained high ( $\sim 6$ million bushels/year total, about $1 / 3$ of which were market sized oysters from the public grounds) until World War I, which decreased both the demand for oysters and numbers of fishers to catch them (Report of the Commission of Fisheries of Virginia, 1945).

Soon after World War 1 ended in 1918, harvests on both public and private grounds declined, with the total harvest falling to 4 million bushels/year by 1920 and never recovering. Production on the public grounds dropped below 2 million bushels/year and fell below 1 million by 1929. Unlike prior declines, this one was met with considerable alarm by fishing industry managers and fishers. Conditions of the oyster rock were described as follows (Report of the Commission of Fisheries of Virginia, 1929): "A survey of the natural oyster rocks on the ocean side of Accomac and Northampton Counties shows that thousands of acres of oyster bottoms, as defined by the Baylor Survey, have become entirely barren. On the bay side of the above named counties the only natural rocks which can be called productive area are a few of those lying in Pocomoke Sound. The natural rocks in Virginia tributaries of the Potomac, including the Yeocomico and Coan Rivers, have become depleted to such an extent that, with a few exceptions, they may be said to be now practically exhausted. The same conditions prevail in the Great Wicomico and York Rivers, in Mobjack Bay and its tributaries, and to a modified extent in the James River below the seed line. Some of the rocks in the Rappahannock and Piankatank Rivers are still comparatively productive, but many of the rocks in these rivers have either become much smaller in area or are now totally barren. These conditions easily explain the falling off in the production of the natural rocks." This decline was attributed primarily to constant tonging and dredging without adequate rest or replenishment of the public oyster grounds. A second factor was oyster drills, Urosalpinx cinerea, a predatory snail on young oysters, which caused $20-40 \%$ mortality on oyster recruits (Report of the Commission of Fisheries of Virginia, 1926-1963, Report of the Virginia Fisheries Laboratory Report, 1953). It is unknown if the snails routinely caused this mortality rate, as this is the first time it was measured, but it is likely they did.

\section{Birth of the Repletion Program}

To address the public fishery decline, the commission recommended that a shell planting program to refurbish the public grounds be initiated and funded at the level of $\$ 100,000 /$ year (\$1.39 million in 2015 USD) with a goal of planting at least 500,000 bushels $\left(22,600 \mathrm{~m}^{3}\right)$ of shells/year on the public grounds in an attempt to halt the decline in productivity. This repletion program began in 1929 with the first shell plantings to attempt to maintain the habitat and seed to more directly augment commercial harvest in specific areas. Seed at this time came from areas of high recruitment, typically the "seed beds" in the James River, the region of the James that had already been providing the majority of the seed oysters to private planters (Report of the Commission of Fisheries of Virginia, 1929). During the first two decades, $\sim 276,000(12,475$ $\left.\mathrm{m}^{3}\right)$ bushels of shells and 15,000 $\left(678 \mathrm{~m}^{3}\right)$ bushels of seed were planted/year. During these early years of the repletion program (1931-1947) shell plants, with a 2-year lag to account for the time needed for recruits on fresh shells to grow to market size, did not have a statistically significant impact (ANOVA, $p>0.05$ ) on the public oyster ground harvest (Figure 4). Seed plantings during this time (1931-1947) were also analyzed with a 1-year time lag being most appropriate considering seed generally took 1 full year post-planting to reach market size. No significant impact (ANOVA, $p>0.05$ ) on the harvest due to these seed plantings was observed. Seed plantings were also examined with a 2 -year lag and this was also not significant (ANOVA, $p>0.05$ ). While it may have had some benefits, and perhaps did in slowing the rate of stock decline, given the limitations of the available data this impact is undetectable. Public ground oyster harvests during this time (1929-1949) averaged 650,000 (29,380 $\left.\mathrm{m}^{3}\right)$ bushels/year, roughly $10 \%$ of what it was during the peak years. Harvests on the public grounds declined further during the 1950 s by $9 \%$ to $596,000\left(26,939 \mathrm{~m}^{3}\right)$ bushels/year (Report of the Commission of Fisheries of Virginia, 1947-1961). In response, the repletion program was augmented in shell planting volume to $676,000\left(30,555 \mathrm{~m}^{3}\right)$ bushels of shells/year though seed plantings, believed to not be of significant help, were halted (Report of the Commission of Fisheries of Virginia, 1929-1949). State general funds were used to supplement the repletion program funding in 1947 , which had prior to this point been funded solely by tax and license fees on the oyster fishery (Commission of Fisheries of Virginia, 1947). The general public therefore began to subsidize the fishery, a 70-year subsidy which continues to this day.

\section{Advent of Oyster Disease and Its Impact on the Fishery and Repletion Program}

In the late 1940s, oyster mortalities were being noted in adult oysters that could not be attributed to predation. The cause was identified as a fungus (actually a protistan parasite) that is now known as Dermo, Perkinsus marinus (Report of the Virginia Fisheries Laboratory, 1949-1959; Andrews, 1979). Estimates of annual mortality during this time ranged from 10 to $30 \%$ of oysters nearing market size in the summer prior to their fall harvest (Report of the Virginia Fisheries Laboratory, 1959). Perkinsus remains a problem to this day, becoming much more severe in Chesapeake Bay in the 1980s (Burreson and Andrews, 1988; Ragone and Burreson, 1993; Burreson and Ragone-Calvo, 1996; Ragone Calvo et al., 2003; Wilberg et al., 2011), when mortalities of adults due to Dermo were over $90 \%$ of age $2+$ adults/year in many areas of the Bay (Figure 2). Mortality has since declined from this peak, but it remains a significant impediment to oyster population recovery at present. Shell plantings increased in volume in response to the increasing mortality on market and near-market sized oysters. The benefit of shell plantings occurred 2 years post planting, the time to grow a single year class of oysters to market size on a shell planting (ANOVA, $p<0.05$ ), though not at 3 or in later years (ANOVA, 
$p>0.05$ ). The amount of increased harvest was estimated using the regression equation on the raw data of the era, to be a $41.8 \%$ increase in commercial harvest due to the shell plants (time period 1950-59, linear regression, $r^{2}=0.63$ ), which was the largest positive impact noted for the shell planting program. No seed was planted on the public grounds during this time. The volume of shells relative to the public ground harvest increased significantly to achieve this benefit, with shell plants now amounting to $105.1 \%$ of the volume of the commercial harvest, compared to $35.8 \%$ by volume in earlier years. Another oyster disease, MSX, Haplosporidium nelsoni, first noted in Delaware Bay in the late 1950s, caused significant mortality to Virginia's oysters starting in 1959. Unlike Perkinsus, which appears to be a native organism, Haplosporidium was introduced into Delaware Bay via importations of non-native Pacific oysters, Crassostrea gigas, from Japan (Burreson et al., 2000). The combined DermoMSX epidemic caused massive oyster (primarily adults of submarket and market size) mortalities (90-95\%) in high salinity waters (>11 PSU) throughout much of Chesapeake Bay by 1960 (Andrews, 1964, 1968; Andrews and Wood, 1967; Andrews, 1979). Harvests peaked in 1960-61 as oyster fishers try to catch as many oysters as possible before MSX killed them; plummeting to 227,000 bushels in the 1962 harvest, the lowest ever seen on the public grounds. The private leasehold fishery also declined with the advent of MSX, production plummeting from $\sim 2,500,000$ million bushels/year during the 1950s to less than 1 million by 1967 . Seed oyster production also declined from 2,300,000 million bushels/year during 1950-1960 to $1,150,000$ million by the early 1960s. As disease reduced stocks and drove down seed counts per bushel, the price per seed oyster rose simultaneously as seed quality declined due to increased mortality from disease (Shabman and Capps, 1984; Bosch and Shabman, 1989). The decline in spat counts per bushel after MSX was introduced to Chesapeake Bay were most apparent in the James River, but also occurred in other Virginia waters (Figure 4) (Burke, 2010). James River seed oysters were particularly vulnerable to MSX disease due to their origin in low salinity (6-10 PSU) waters, which inhibit natural selection for disease tolerance as MSX does not thrive in such waters (Ford, 1985). After the initial MSX epidemic, oysters in high salinity waters developed some tolerance to the disease (Ewart and Ford, 1993) which appears to have become significant in recent years (Carnegie and Burreson, 2011) though low salinity populations remain naïve and subject to significant mortalities if relocated to high-salinity waters.

The MSX disease epidemic of the 1960s initiated the first of three waves of Federal economic subsidies to the Virginia oyster industry. The response to the James River seed problem was to develop two smaller rivers in higher salinity waters as seed oyster sources for the private leasehold fishery, the Great Wicomico and Piankatank Rivers, which began to receive large scale shell plantings in the early 1960s as part of both state and federal oyster disaster relief effort along the Northeast Coast of the United States. The federal funds were used to support research into disease resistant oysters as well as rehabilitation of oyster beds via shell plantings and through seed purchase and movement (Report 1736, 87 $7^{\text {th }}$ Congress, 1962). This larger scale shell planting effort also involved adding shells obtained by dredging buried shell deposits from local waters to shells bought from shucking houses,. During the peak of the shell planting program in Virginia (1963-1968) 2,600,000 bushels $\left(117,520 \mathrm{~m}^{3}\right)$ of shells were planted/year. The oyster seed planting program was also re-initiated at this time (1961) in response to the MSX epidemic, to move oysters from high salinity regions where they recruit in good numbers to low salinity areas where MSX mortalities were lower and survival of planted seed to market size $(76 \mathrm{~mm})$ more likely. In prior years when seed was moved onto public grounds (1931-1946) an average of 18,700 bushels $\left(845 \mathrm{~m}^{3}\right)$ /year were moved. From 1962 to $1972,73,400$ bushels of seed oysters were moved, which amounts to $21.5 \%$ by volume of the commercial harvest from the public oyster grounds. Considering that planted seed can potentially produce over a bushel of market oysters per bushel planted depending on survival and growth rates, this seed movement could have made a significant contribution to the commercial oyster harvest during the peak years of the MSX epidemic (Report of the Commission of Fisheries of Virginia, 1931-1965).

\section{Post MSX Period (1964-1980)}

The large scale shell plantings and seed movement may have exerted a positive effect on the public oyster fishery as harvests, despite ongoing though declining but still significant MSX mortality (Andrews, 1968), which appears to have peaked during the early 1960s (Mackenzie, 1996). However, statistical analysis indicates there was no clear relationship between shell or seed plantings and the public oyster harvest with the exception noted (1950-59). ANOVAs on harvest vs. repletion program (with a 2 year stagger for shell plants and a 1 year stagger for seed plants) from the entire time of the repletion program (1931-2009), and various eras selected for times of more intense shell and/or seed plants after the MSX epidemic: 1960-1985, 1991-2009, 2000-2009, 2005-2009, 1960-1969, 1960-1971, and 1963-1966 revealed no significant relationships, $p>0.05$ ). Shell plants and seed plants were factors, considered independent of each other as well as interactively using $\mathrm{R}$ software, as were all subsequent ANOVA of various time periods, with harvest as the dependent variable. Harvests from the public oyster rocks vary considerably during this time, from a low of 228,000 bushels in 1962 to just over 600,000 bushels by 1965 . Harvests decline again (> 300,000 bushels/year) from 1967 until after Tropical Storm Agnes in 1972 (Report of the Commission of Fisheries of Virginia, 1907-1980).

Tropical Storm Agnes had a significant negative impact on the oyster industry, but it also exerted a positive impact by virtually extirpating the predatory oyster drill from much of Chesapeake Bay, particularly the Rappahannock, Piankatank, and Great Wicomico Rivers, and severely depleting them in the York and James Rivers (Lynch, 2005), allowing for greater survival of young oysters. The heavy freshwater flooding caused by Agnes also inhibited seed oyster production due to the very poor recruitment on seed beds. Mortality due to the storm on private leaseholds (Report of the Commission of Fisheries of Virginia, 1907-1980) was much higher than on natural reefs. The public ground harvest stayed steady while the private ground harvest plummeted to $\sim 33 \%$ of the prior year's harvest. The private leasehold fishery did not recover and production remained $<50 \%$ 

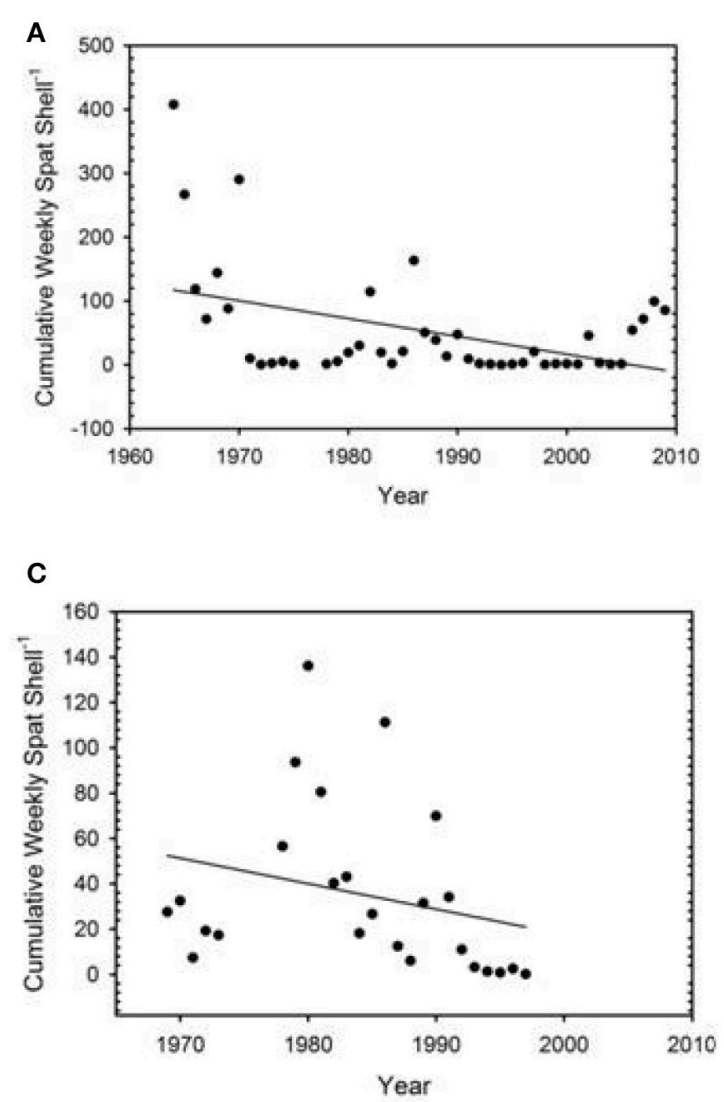

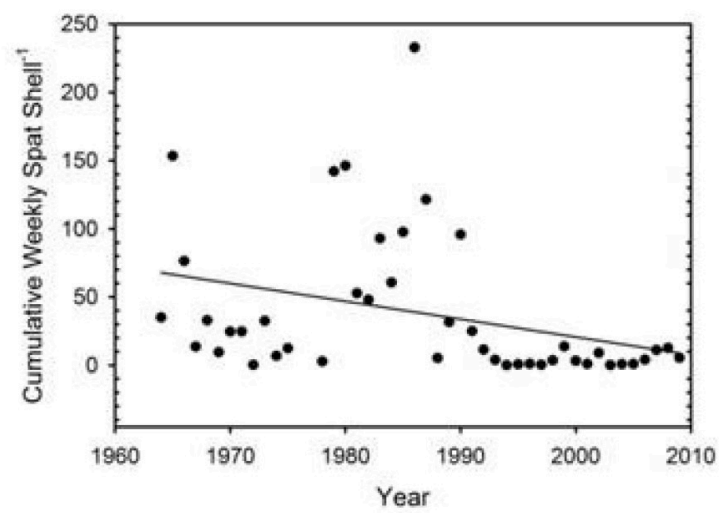

D

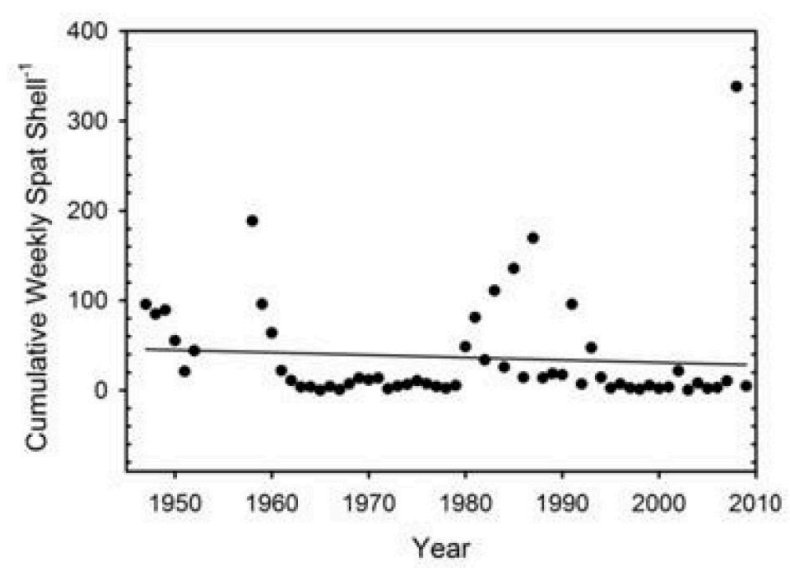

FIGURE 4 | Mean spatfall over time in various Virginia tributary rivers over time. (A) Great Wicomico River, (B) Piankatank River, (C) Mobjack Bay, and (D) James River.

of the decade before. Federal disaster relief funding resulted in massive shell plantings for several years, rapidly increasing after 1972 to a peak of over 3,000,000 bushels $\left(135,600 \mathrm{~m}^{3}\right)$ of shells planted in 1975 and 1976. Harvests increased from 260,000 in 1972 to over 700,000 bushels of oysters in the 197980 harvest seasons. This peak was the highest since 1961, and the last significant peak in production for the public oyster fishery (Report of the Commission of Fisheries of Virginia, 1907-1980).

\section{Final Decline and Collapse with Recent Signs of Recovery (1981-Present)}

Seed movement, which had increased to over 100,000 bushels a year in the early to mid-1970s, was reduced to less than 50,000 bushels/year from 1975 to 1986 . Large scale shell plantings on public grounds also declined from over 3,000,000 bushels $\left(135,600 \mathrm{~m}^{3}\right) /$ year in the mid-1970s to less than half that total in the following decade $\left[\sim 1,400,000\right.$ bushels $\left(63,280 \mathrm{~m}^{3}\right)$ shells/year from 1977 to 1986]. Harvests from the public grounds declined along with the shell plantings, falling over 50\% from 1980 to 1984. The years 1985-86 were very dry and hot, especially during the time when oysters and their diseases are metabolically active, permitting Perkinsus to overwinter at high prevalence. In typical years reduced winter salinity and temperatures promote reductions in disease prevalence and intensity (including MSX). This allowed for an expansion and increased virulence of Dermo throughout most of the Chesapeake Bay causing massive mortalities of adult oysters (Andrews, 1996) in almost all Virginia waters. MSX also played a role in increasing disease mortalities at this time, especially in Maryland, though Dermo was the primary source of disease mortality during this epidemic. As stocks of market sized oysters declined precipitously in almost all Virginia waters, the situation for the oyster industry grew dire. The result was the unprecedented move by fishery managers to open the James River seed beds to harvest for market oysters in 1986. Another action was to allow hand scrapes, which are small oyster dredges, for use in the oyster fishery and the opening up of many regions to their use in 1987 in an attempt to maintain harvests (Virginia Marine Resources Commission 1986-1987). Dredges, pulled over a wide area of reef, catch more oysters per unit time than tongs when oyster densities are low. These management measures enhanced harvests for several years before populations were depleted. It was believed that as disease would soon kill the oysters, it was best to attempt to harvest them. The James River seed beds were managed over much of their former area for market oyster production. Shell and seed plantings to maintain the public grounds continued, shell plantings averaged 
$\sim 1,500,000$ bushels $\left(67,800 \mathrm{~m}^{3}\right)$ /year planted and 80,000 bushels $\left(3,616 \mathrm{~m}^{3}\right)$ of seed/year planted from 1981 to 1990 (Virginia Marine Resources Commission, 1981-1990, Hargis and Haven, 1999). Public ground harvests during this time average 322,000 bushels of oysters/year, steadily declining during this time from 475,000 in 1981 to 178,000 in 1990 , a $73 \%$ drop, and now at $3 \%$ of the historic peak. The Dermo outbreak also impacted the private leasehold fishery, which declined from 300,000 bushels/year from $1980-1986$ to less than 100,000 by 1990 . The state cut its public oyster repletion program drastically (by $81 \%$ ) in 1991, and remained low until very recently (2013) when much more substantial state funding ( $\$ 2 \mathrm{M}$ USD) was provided to allow the repletion program to expand again. The Federal government began providing funds in the 1990s. These funds exceeded state funding for a significant period of time (Virginia Marine Resources Commission, 1993-2010) decreasing after 2010. From 1993 to 2011, on average nearly 767,000 bushels $\left(34,668 \mathrm{~m}^{3}\right)$ of shells have been planted/year on public oyster grounds to maintain the fishery, along with an average of nearly 30,000 bushels $\left(1,356 \mathrm{~m}^{3}\right)$ of seed oysters (wild and in recent years some hatchery produced) planted annually on these same grounds. At the same time, oyster harvests on the public grounds have been very low, 42,426 bushels/year on average. These repletion numbers do not consider reefs constructed as sanctuaries, which are closed to oyster harvesting, or any oysters planted on these sanctuaries. If these were included, both shell and seed figures would be much higher (Virginia Marine Resources Commission, 1986-2011). Public oyster harvests declined further, recording harvests of less than 10,000 bushels for several years in the 1990s, 2001 and 2006. The only harvest exceeding 100,000 bushels occurred in 2005 when a large sanctuary established in the James River in the 1990's was opened to commercial oyster harvest (Daily Press, 2005). This sanctuary supplied the majority of the 2005 public harvest total of nearly 100,000 bushels. Another large sanctuary in the lower Rappahannock River that had been closed to commercial oyster harvest in 1993 was opened to harvest in 2007, enhancing harvest that year, though. Public ground harvests remained lower than 100,000 bushels/year until recently (post 2010). Further management actions taken at the time of the Rappahannock River sanctuary opening included establishment of a rotational harvest system in the lower Rappahannock River and in the Tangier/Pocomoke Sound region, dividing them up into regions so that individual public grounds are rested for a year between harvests and also to better coordinate repletion activities to maximize commercial harvest (Virginia Marine Resources Commission, 1986-2007). It is believed that this allows for higher stock and harvest levels. It is unknown at this time if this management is having this affect, as there has been developing disease resistance, which has also enabled higher harvests post 2010. Rotational harvest has been used successfully for molluscan species, including sea scallops (Valderrama et al., 2007). Due to the present lack of wild seed resistant to disease, there has been a significant increase in production of oyster seed from hatcheries for aquaculture, either on the bottom or in more managed cage and rack systems (Murray and Hudson, 2011), this trend continues at present. In recent years, hatchery produced seed has significantly augmented the private leasehold productivity, which has out-produced the wild oyster fishery in terms of bushels of market oysters produced/year since 2006 with this gap widening significantly in the past several years. This increase has been primarily due to the development of hatchery produced seed, not increased wild seed production, though wild seed production has increased in recent years as well.

In Virginia, three formerly productive oyster beds of varying size at the confluence of the Nansemond, Elizabeth, and James Rivers (1037.4 ha) and in Tangier Sound (284.6 and 479.4 ha) were permitted for dredging of buried shells that formed the footprint of these large historical reefs. They were denuded of live oysters and surface shell by years of overfishing and covered by $\sim 0.6 \mathrm{~m}$ of sediment as of 1960 (Withington, 1965). The largest site had been depleted by 1850 (Paxton, 1858) and the two smaller sites by the 1870s (Winslow, 1882). This dredging of former reef footprints commenced in Virginia in 1963 and continues at present. The three initial sites, which contained unconsolidated deposits of shells up to $4 \mathrm{~m}$ thick served for many years of shell dredging (Withington, 1965). These initial three sites were eventually depleted and are no longer used today. Several small sites in the lower James River totaling $\sim 114$ ha are permitted for use at this time. The majority of shells planted in Virginia waters in recent years have been dredged shells, with shucking house shells comprising a smaller portion $[\sim 500,000$ bushels $\left(22,600 \mathrm{~m}^{3}\right) /$ year]. Most of this shucking house shell was not derived from local harvests but from imported shell stock from the Gulf of Mexico, as the few remaining (161 in 1981, 36 in 2009) oyster shucking and packing houses in Virginia primarily imported and processed live oysters from the Gulf of Mexico until the Deepwater Horizon oil spill in 2010 impacted a significant part of the gulf oyster fishery, causing a wide-scale closure of most of it (Sumaila et al., 2012) and the increasing local harvests in recent years.

\section{Shell Placement}

Shells were generally placed to sustain the commercial harvest by repairing damaged habitat. However, there have been significant exceptions. At the commencement of the shell planting program in the late 1920s, a number of experimental shell plantings were conducted to assess the benefits of expanding oyster habitat. The results when compared to planting shells on existing, damaged and depleted habitat were poor. State fishery management developed a position in 1931 (Report of the Commission of Fisheries of Virginia, 1931) as follows: "The planting of shells on barren grounds, and then closing the areas on which they are planted until there is a sufficient catch of oysters of marketable size, as the statute now provides, will not, in the opinion of the Commission, produce satisfactory results for the reasons, that there is frequently a failure to obtain a catch of young oysters on such grounds, and when they are once thrown open to the public, the repleted areas soon become as barren as they were before the shells were planted. Furthermore, the cost of restoring the natural rocks on barren bottoms in Virginia would be too great to be considered. On the other hand with shells planted on the live, productive rocks, and the cull law enforced, there is not only a better chance to obtain a catch of young oysters on the shells year by year, but they would afford a continual means of 
production." However, accuracy of shell placement was limited by navigational technology to locate accurately the bed to be planted, as well as the means to place the shells (typically a water cannon of the type used on marine fire control vessels was used to blow shells off a barge) as well as currents which can displace shells as they settle to the bottom. This had been noted as early as 1950, when the Virginia Fisheries Laboratory "recommends an annual survey of the public oyster rocks in order to determine more accurately the location in which shells should be planted for cultch purposes (Report of the Virginia Fisheries Laboratory, 1949-1959)." Extensive experimental plantings outside typical repletion done on natural oyster rock habitat commenced with the influx of Federal funding in the 1960s that was allocated to Virginia in response to the MSX disease epidemic. However, it remained state fishery management policy to spend the bulk of the repletion efforts on areas of known productivity: "It is our intention to continue planting the largest quantity of shells in the tried and tested areas although we expect to make experimental plantings in other rivers where we hope to get enough recruitment to further advance the program" (Report of the Commission of Fisheries of Virginia, 1964-1965). These experimental plantings continued to be part of the repletion program for several years, throughout the late 1960s. They evidently continue to some extent to the present time, as in the Rappahannock River and Tangier/Pocomoke Sound which show that portions of recent repletion projects (year 2000 and more recent) have included significant shell plantings on new areas rather than on natural oyster rock (Figures 5-7).

\section{Oyster Fishers}

The total number of fishers is considered, and fishermen types are often grouped for the analysis as harvest data by gear type is limited. Two main distinctions in gear type define the type of fisher: tongs, which are large metal-toothed rakes that are worked by hand or hydraulically, and dredges, which are metaltoothed frames with an attached bag that are pulled over the bottom by the boat. Tongs take a discrete, small area of reef per deployment whereas dredges are dragged over an area of reef per deployment. Dredges are more efficient oyster harvest gear both in deeper waters and lower market oyster densities (Tarnowski, 2004). Dredges are more damaging to the reef structure than are tongs, and additionally, over time, spread the remaining reef material over a wider area, expanding it while reducing reef quality (Winslow, 1881; Moore, 1910; Lenihan and Peterson, 1998, 2004). Tongers (hand and patent) dominate the fishing license holders numerically with few exceptions; 1989 and 2004present, when dredgers dominate. Legislative protection has been provided to tongers throughout the history of the fishery, reserving large areas, typically in rivers and shallower waters, for their exclusive use. This permitted larger numbers of watermen to remain in the fishery at the expense of individual income. This recent dominance by dredgers is largely due to the permitted use of smaller dredges, called "hand scrapes" into the oyster fishery in the late 1980s over much of Virginia's public oyster grounds. Prior to the Dermo epidemic, dredgers constituted 10\% or less of the total fishers in Virginia. Maryland reacted similarly to the Dermo disease epidemic, opening up wider and wider areas to oyster dredging as oyster populations collapsed in an attempt to sustain harvests (Tarnowski, 2004). This management action resulted in more rapid and complete population collapse in Maryland. Further, the Dermo induced collapse may have been avoided had fishing mortality been decreased (Rothschild et al., 1994; Jordan and Coakley, 2004) and though this has not been extensively studied in Virginia, it is likely true for the Virginia oyster population as well. For example, in 1978, dredging was declared legal during a short, designated late winter season each year in open waters of Tangier and Pocomoke Sound, Virginia. As a result, landings increased to 208,130 bushels for Pocomoke and Tangier Sounds combined during the 1978-79 season, but this level of production quickly declined to only 27,370 bushels in Pocomoke and Tangier Sounds by the 1983-84 harvest season. The data, and the Maryland experience suggest the accumulated stocks were quickly exhausted by the more efficient (and damaging) dredging over tonging during the height of the Dermo epidemic (Virginia Marine Resources Commission, 1978-2011).

As harvests declined fishermen exited the fishery (Figure 8) until stabilizing after the final collapse (1993-2011) at a mean of 481 watermen per year holding active licenses to harvest oysters from the public grounds. Income per license holder also varies considerably (Figure 8), and a recent trend toward higher income/fisher can be seen, beginning around 2004. This has been attracting more fishers back into the oyster fishery, with 594 in 2008, increasing to 908 licensed fishers as of the start of the 2011 season. Due to the fact that all licensed fishermen are grouped, the income/license is not truly reflective of the average income/fisher. Dredgers harvest proportionally more oysters/license than do tongers, though their capital outlay is typically higher. Additionally, dredgers typically operate on larger boats with a crew of two (hand scrape fishers) or more, whereas tongers tend to operate with a crew of one (just the license holder) or with a single helper. During the earlier history of the fishery, crew often consisted of unpaid young $(<18$ year old) sons of adult watermen, forced conscripts (typically recent European immigrants), who were paid poorly if at all (Keiner, 2009), to today's crews where the boat owner will be paid the most with smaller amounts to various crew members, if present.

What can be seen over time is a general downward trend in gross income (adjusted to 2011 dollars) per license-holder over time coupled with a decline in license-holders over time (Figure 8). This trend is accompanied by a transition from oyster fishing as providing near full-time occupation to seasonal employment. The early years of the fishery (18801928 ) saw the average license-holder earn $\$ 12,277$ USD (inflation adjusted for 2011). For the era, this was a below average income (average income from 1913 to 1928 was $\$ 16,098$ USD in inflation adjusted 2011 dollars (Piketty and Saez, 2003), illustrative of the low income typical of a commercial fishermen in the Bay that continues to this day. For example, at Tangier Island, Virginia, a small, isolated community whose workers largely derive their income from commercial fishing, had a median household income of $\$ 28,384$ USD in 2011, compared to the US median of $\$ 49,445$ USD in 2011 (Lebergott, 2017). Today, the oyster fishery provides limited 


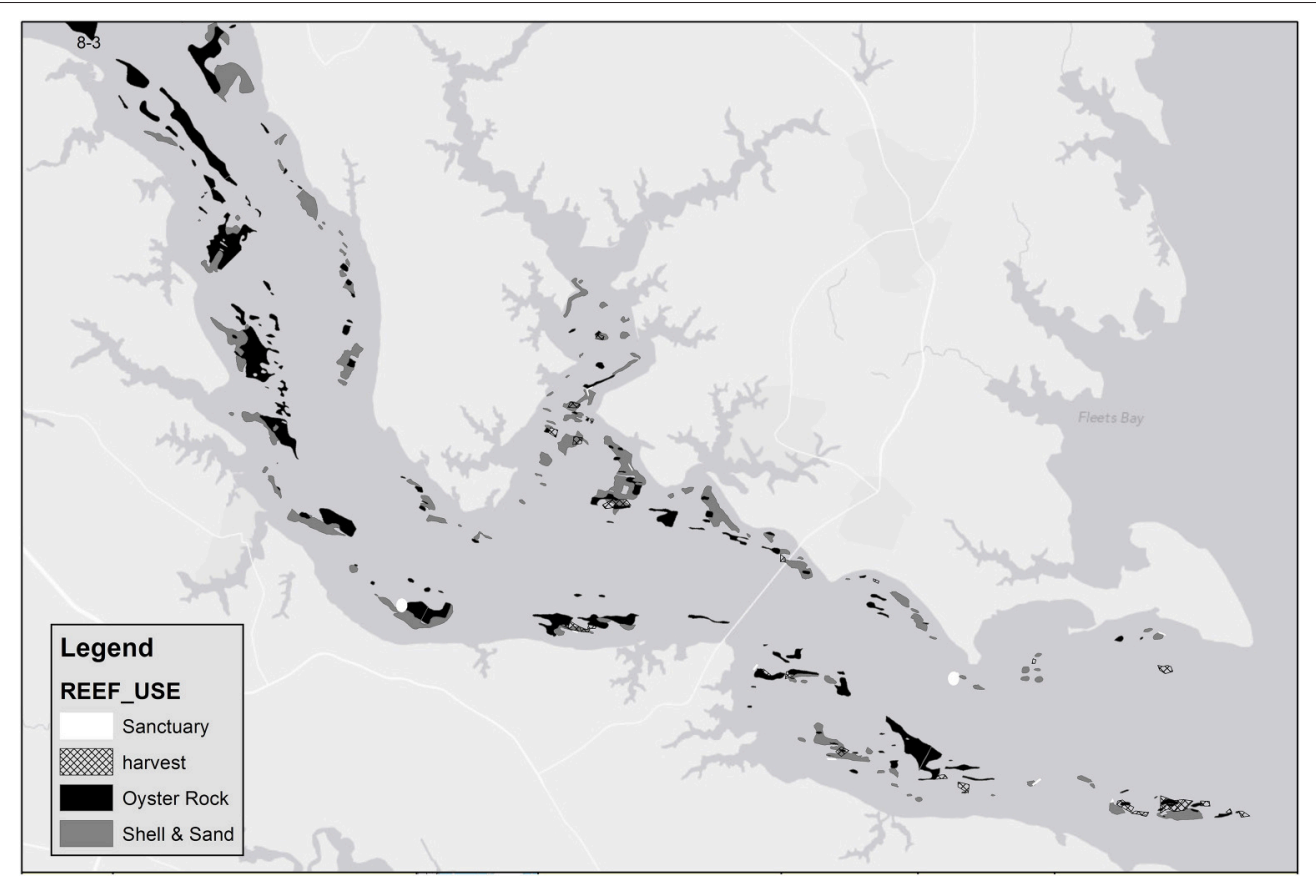

FIGURE 5 | Shell placement in the Rappahanock River, early 2000's. Note a large portion of the shells were not placed on the highest quality "oyster rock" bottom areas.

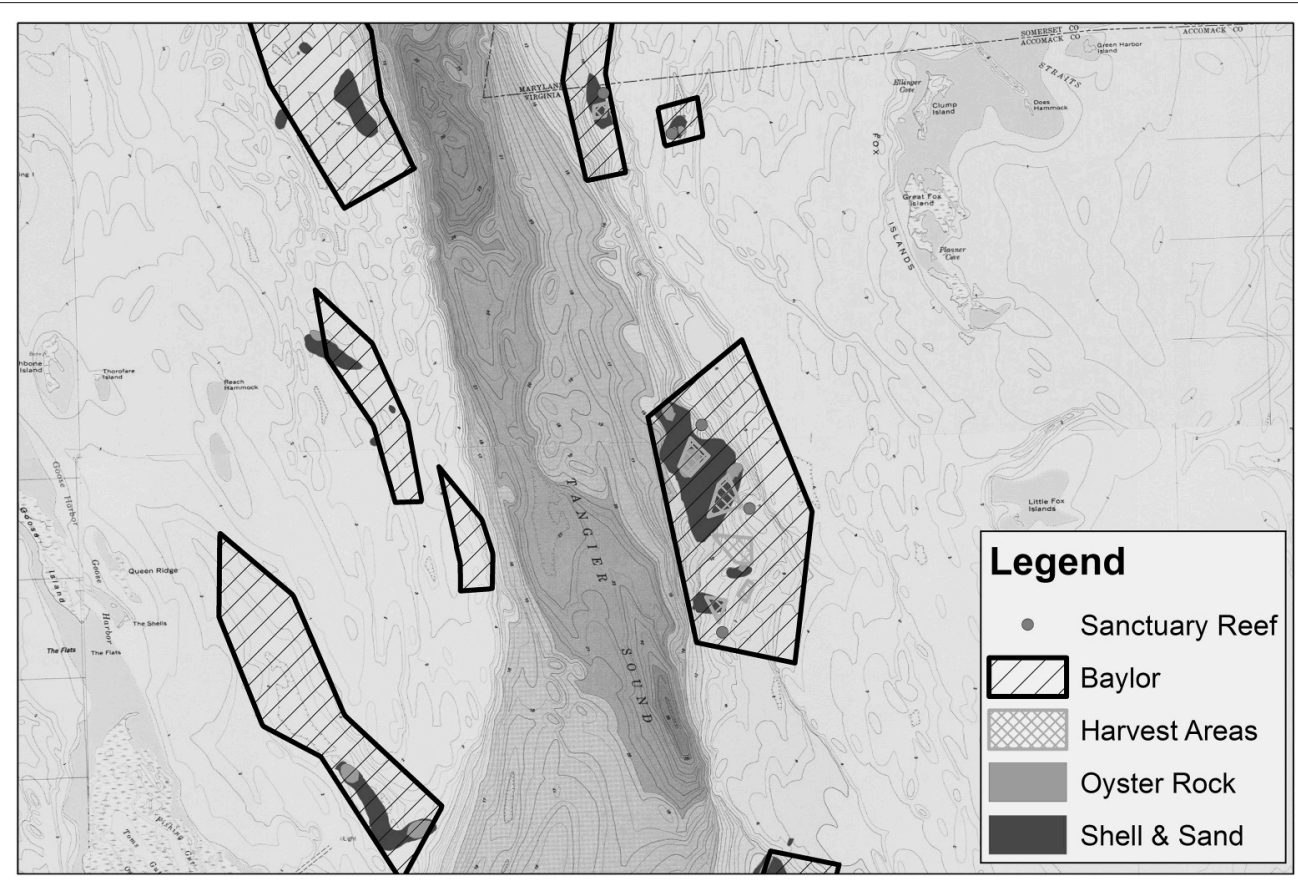

FIGURE 6 | Shell placement in TangierSound, 2002. Note a large portion of the shells were not placed on the highest quality "oyster rock" bottom areas.

seasonal employment to a small number of fishermen, who rely on more destructive fishing practices (dredges) than earlier times, to maintain the small public ground harvests seen today.

\section{Extent of Oyster Habitat and Loss Over}

\section{Time}

The total area originally delimited in Virginia waters of Chesapeake Bay as public oyster grounds was 81,429 ha, with 


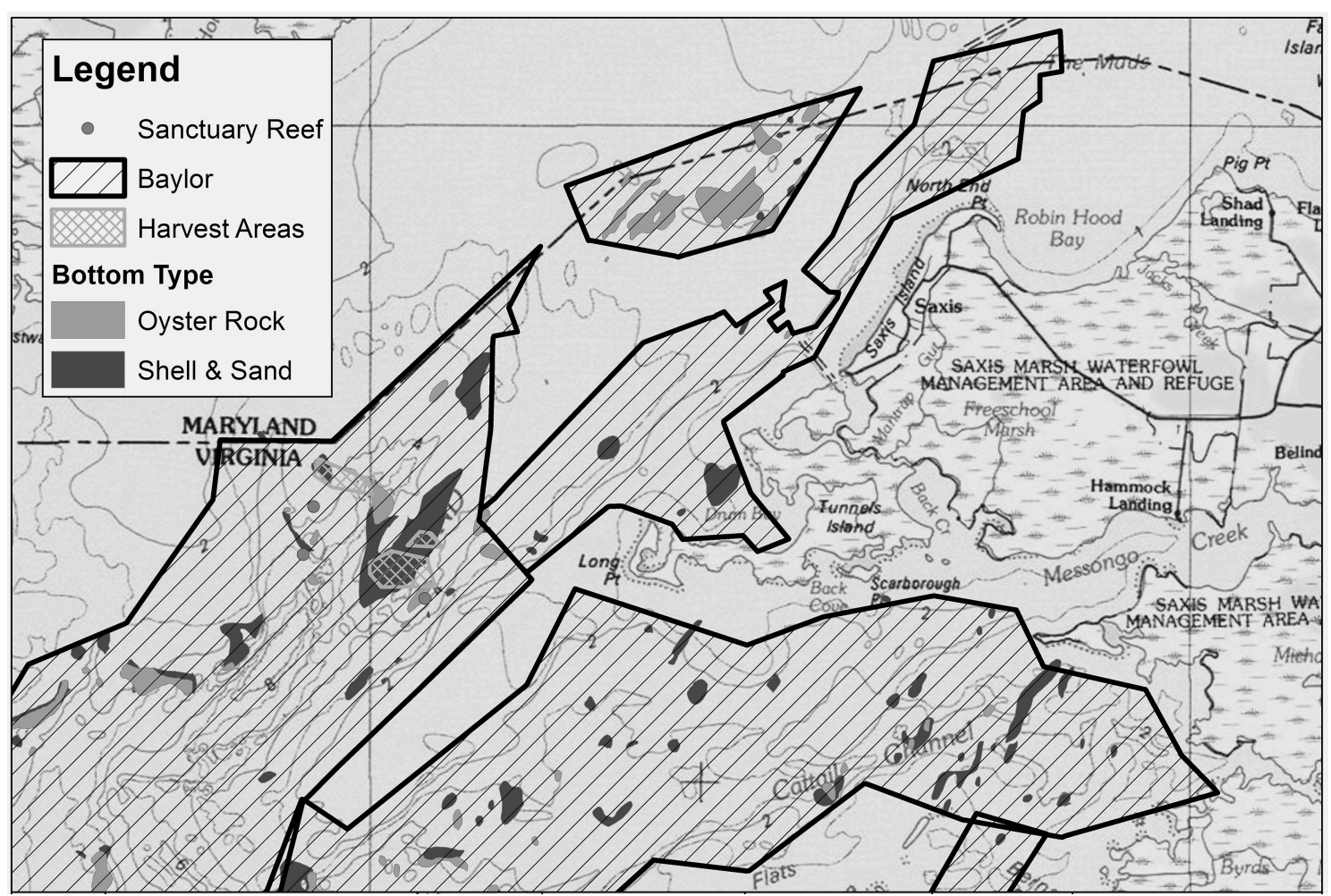

FIGURE 7 | Shell placement in Pocomoke Sound, 2002. Note a large portion of the shells were not placed on the highest quality "oyster rock" bottom areas.

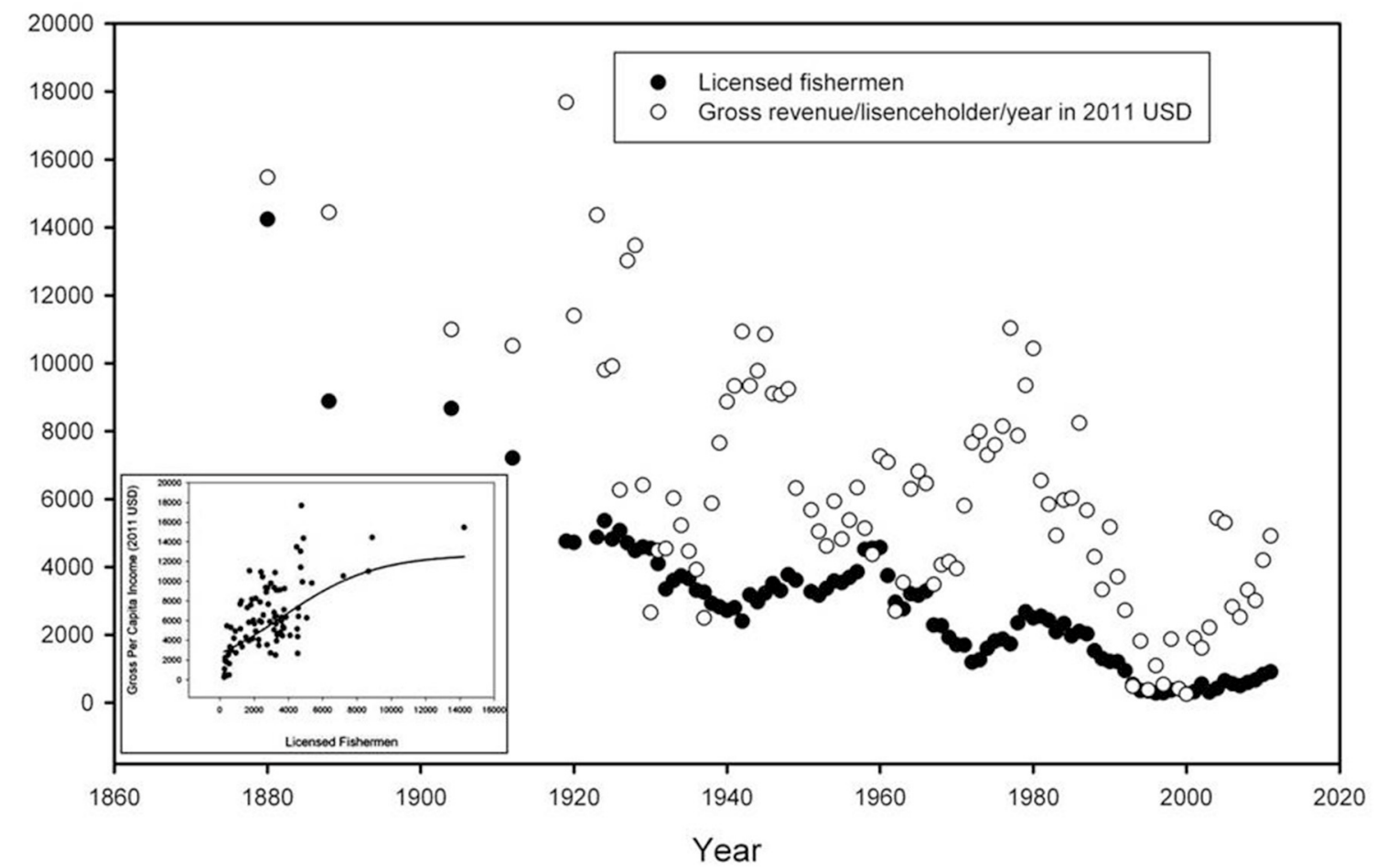

FIGURE 8 | Number of fishers and gross income over time. Embedded graph is a sigmoid fit of the data, $y=12723.3 /\left(1+e-((x-3623.0) / 2717.7), r^{2}=0.43\right.$. 
18,046 ha of these on the seaside of the Eastern Shore of Virginia (Baylor, 1895). Baylor mapped the beds based solely on the input of the county oyster inspectors, who served as his guides, without any ground truth examinations of the bottom.

This means of delineation resulted in numerous discrepancies between where oyster reefs were actually located and the mapped public grounds, with some reef areas kept out and barren areas included. Perhaps the largest discrepancy was that one entire region, much of the lower Bayside Eastern Shore, was not surveyed by Baylor due to the prior decimation of the reefs in this region (Paxton, 1858). In the Lynnhaven River, Baylor was prohibited by the oyster inspectors from surveying much of the Eastern and Western Branches of the River, due to the inspectors' desire to keep such areas out of the public oyster fishery (Baylor, 1893).

The result of the Baylor survey was a series of polygon maps that can serve as a crude guide of the locations and areal extent of oyster grounds, with extensive reef areas excluded in some cases and barren areas that were not oyster habitat included within them. A schematic of the Baylor Survey vs. an older survey (Winslow, 1882) that was subject to a meticulous bottom survey to determine the extent and quality of oyster habitat within the same area, the Tangier/Pocomoke Sound region of mid Chesapeake Bay, shows significant discrepancies (Figure 9). Areas that were undoubtedly oyster habitat were excluded from the survey, based on the borders of a number of oyster reefs that clearly extend off of the Baylor Grounds, and areas that clearly were not oyster habitat were included within the Baylor polygons. To further confound the issue, these surveys (both Winslow, 1882, and Baylor, 1895) were conducted after decades of dredging and it is likely that reef habitat was already lost by this time. Areas covered by ground-truth surveys include the Tangier/Pocomoke Sound region of the Bay main stem (Winslow, 1882), the upper western shore of Virginia waters of Chesapeake Bay (Bradford, 1881), Onancock and Pungoteague Creeks (Bradford, 1881), and the James River (Moore, 1910).

Tonging and dredging damage reefs and can reduce their areal extent as well as reef height (Winslow, 1881; Wennersten, 1981; DeAlteris, 1988; Lenihan and Peterson, 1998; Hargis and Haven, 1999). As an example of tonging impacts, the Moore (1910) survey delineated 2852 ha of high-quality oyster reef habitat (oyster rock) in the James River. Such habitat consists of mostly live and dead oysters and shell, with minimal if any exposed sediments of other types on the reef surface. A more recent survey (Haven et al., 1981) delineated 1,744 ha of oyster rock habitat in the same river, a $38.9 \%$ loss largely between 1906 and 1979 (71 years), for an annual loss rate of $0.55 \% / y e a r$ (Figure 10) due primarily to tonging though sedimentation plays a role by covering depleted beds (Lenihan, 1999), rendering them useless for oyster recruitment. For an example of dredging impacts, Winslow (1882) surveyed the Tangier/Pocomoke area of the Bay main stem. At the time of his survey, there were 2,252 ha of oyster rock habitat in Virginia waters. The Haven et al. (1981) survey documented 630 ha of oyster rock remaining, a 72\% loss over the period 1878-1979 (101 years) for an annual rate of $0.71 \% /$ year (Figure 9). A creek in this region, Pungoteague
Creek, also illustrates this damage and resultant habitat loss (Figure 11).

Repletion rates were different between the two regions (Reports of the Commission of Fisheries of Virginia 1929-1967; Annual Reports of the Marine Resources Commission, 19681978), with the James River oyster rock receiving, on average, $89.7 \mathrm{~m}^{3}$ of planted shells/ha and Tangier/Pocomoke Sound oyster rock receiving, on average, less at $50.5^{3} /$ ha since the inception of the repletion program to 1978 (the year before the Haven survey was conducted) compared to the original surveyed rock areas. Plantings often occurred in the same areas known to be particularly productive or due to political pressures, so these averages are not truly reflective of what actually occurred-some areas were preferentially maintained, while others may never have had any shell planted. The higher rate of repletion in the James River may have slowed its rate of areal shrinkage compared to the Tangier/Pocomoke region, which may explain the lower rate of habitat loss, though it is more likely due to a combination of higher initial relief of the James River reefs compared to those in Tangier/Pocomoke Sound as well-differences in fishing devices. Overall, these rates of habitat loss are comparable to those estimated for the Maryland portion of Chesapeake Bay's oyster habitat (Rothschild et al., 1994; Smith et al., 2005).

It is also probable that new habitat was formed by the extensive dredging of the reefs, which spread shells over a wider area than the original pre-exploitation reefs covered. Winslow (1882) and Ingersoll (1881) indicated that this was the case. Modern experiments (Lenihan, 1999; Lenihan and Peterson, 2004) demonstrated that oyster dredges spread reef material over a wider area when run over reefs with significant bottom relief, as most early reefs did (DeAlteris, 1988; Woods et al., 2004) in Virginia waters of the Bay. The "scattered" areas in the Winslow survey $(1881,1882)$ were, in part, new habitat formed by spreading of shells from the original reefs.

\section{DISCUSSION}

The public oyster fishery follows the typical pattern of depletion seen for most oyster fisheries worldwide (Kirby, 2004; Beck et al., 2011). Today, the remaining oyster habitat in Virginia waters in the Bay is in generally poor condition and stocks are low. The fishery is defined as collapsed (Worm et al., 2006; Costello et al., 2008), as both public and the linked private leasehold fishery returns are much less than $10 \%$ of peak landings $(0.5 \%$ for the public fishery and $0.8 \%$ for the private leasehold fishery since the early 1990's. Most of this loss can be attributed to overfishing compounded in later years by disease (Haven et al., 1978; Hargis and Haven, 1999; Kirby, 2004; Beck et al., 2011), coupled with inadequate stock management during disease epidemics (Jordan and Coakley, 2004). It is possible that diseases increased as stock declined due to allee effects, which have been implicated in fishery collapses, including molluscan fisheries (Gascoigne and Lipcius, 2004) but this has not been confirmed for Chesapeake Bay oysters.

The oyster repletion program, a put-and-take fishery subsidy, operated in the early years with little impact, though it likely 


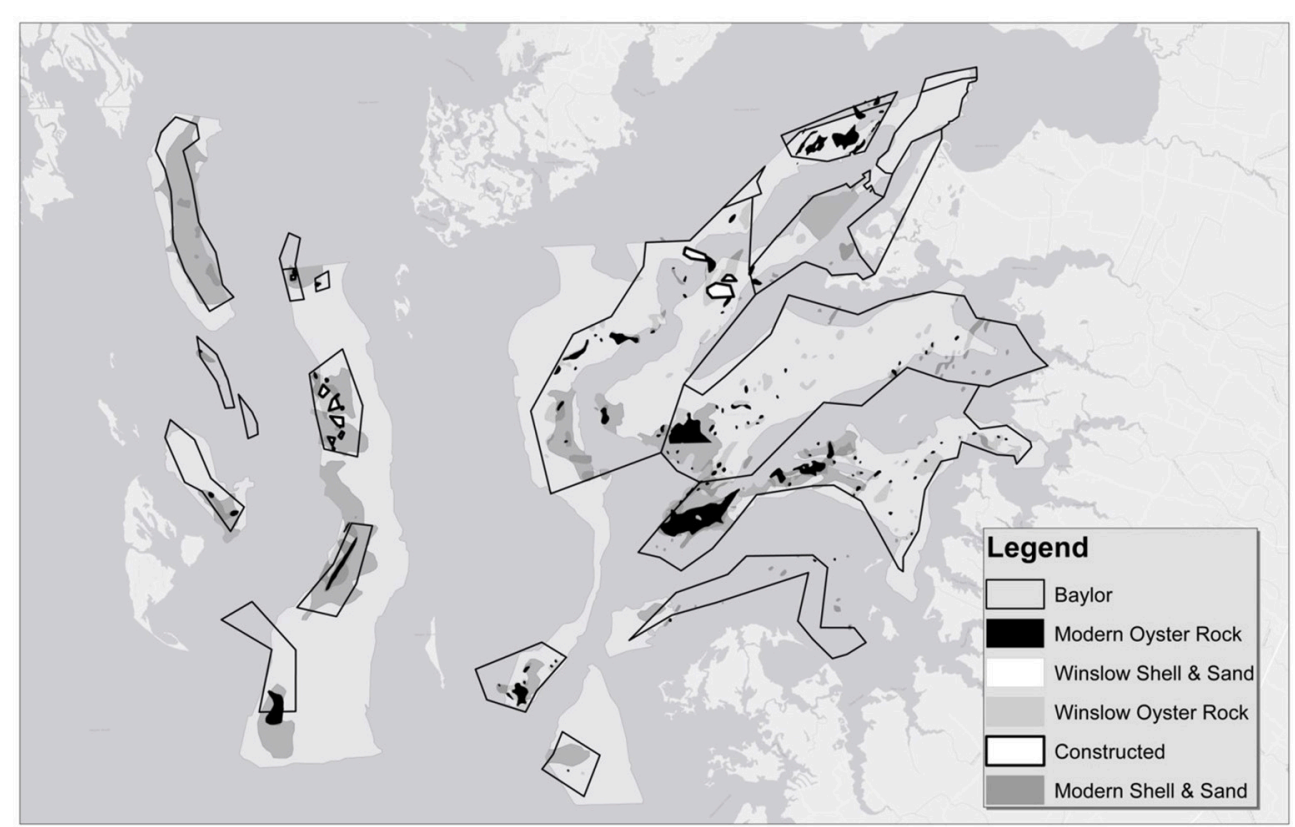

FIGURE 9 | Map showing Baylor (1895) grounds (polygon outlines), Winslow (1882) survey (medium grey = Winslow oyster rock, very pale grey = Winslow shell and sand, and Haven et al. (1981) survey (black = Modern oyster rock, dark grey = Modern shell and sand, bright white polygons are where modern (post 2000) shell plantings have been constructed) of Tangier and Pocomoke Sound waters, VA.

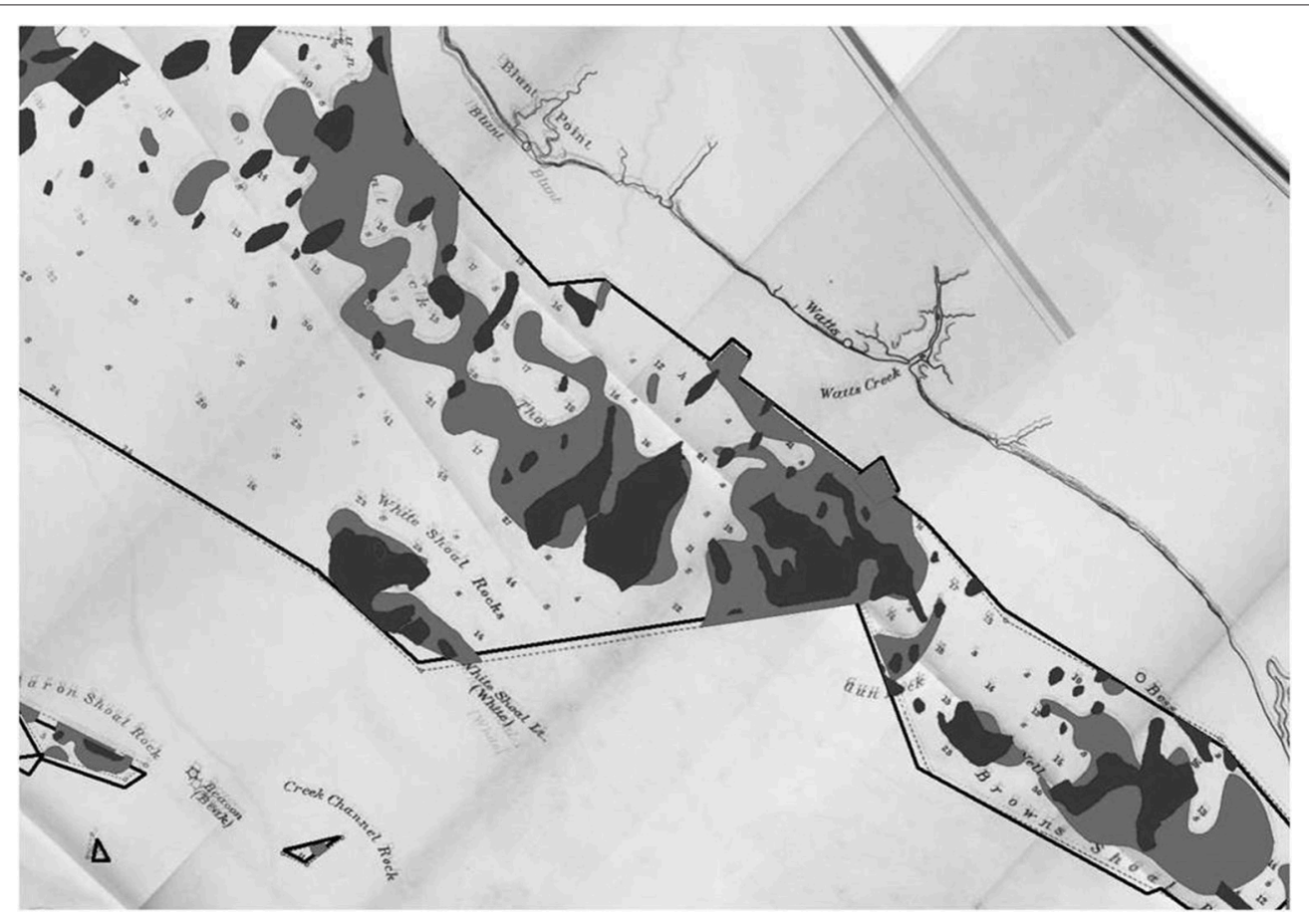

FIGURE 10 | Habitat loss between Moore Survey (1910, gray areas) and Haven et al. Survey (1981, black areas) in the James River.

played a role in sustaining harvests and slowing the rate of the collapse of the public fishery. When the shell-planting program was sufficiently large, a positive benefit of increased harvests on public oyster grounds was observed. Overall, repletion efforts in Virginia increased exponentially over time with increasingly larger efforts (and associated expenditures) needed per bushel of market oysters harvested from the public oyster grounds after each disease outbreak. The dredged shells used for the majority of the shell plantings since the early 1960's currently cost $\$ 2.00 /$ bushel (this price continues to rise) and oyster seed used 


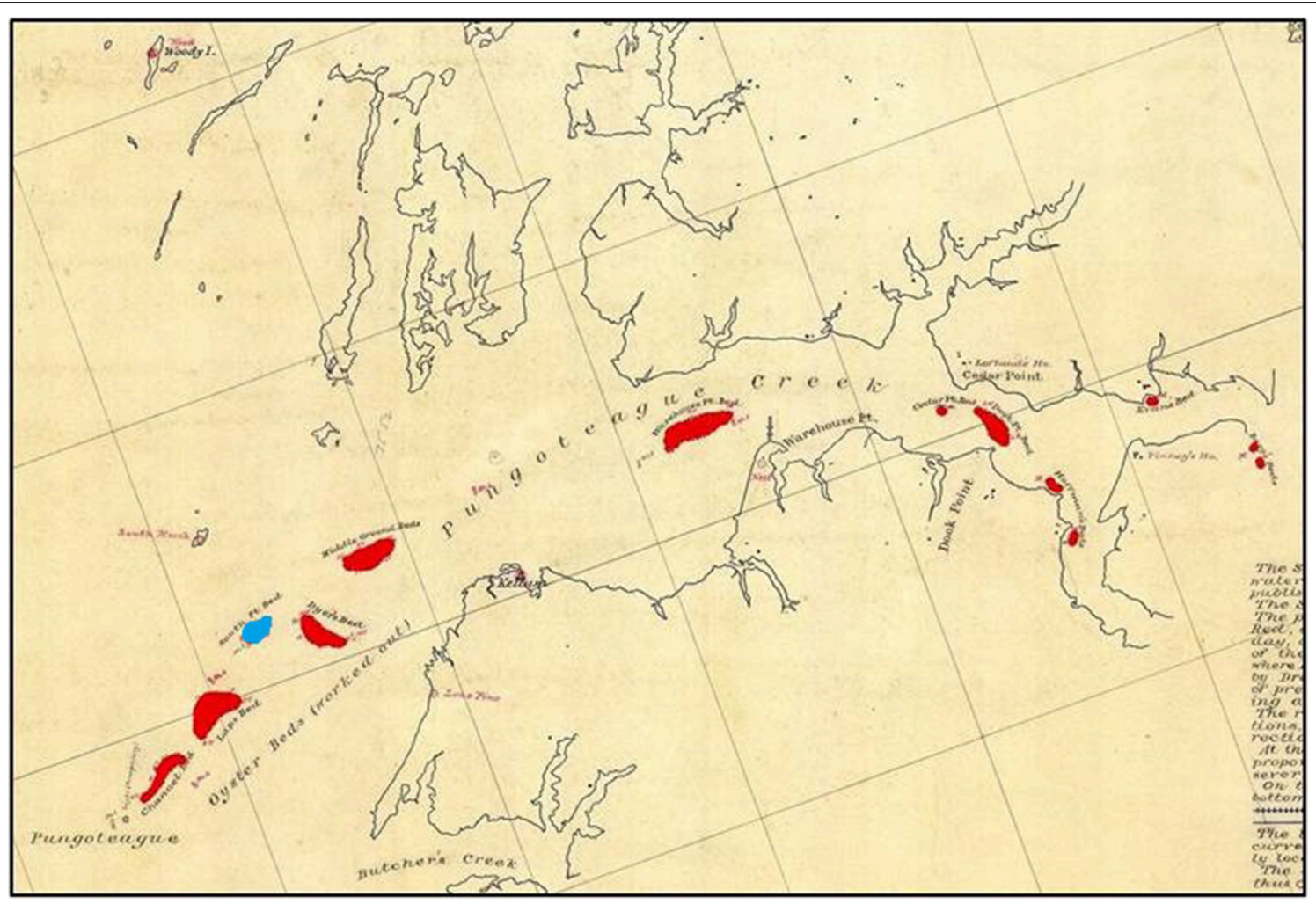

FIGURE 11 | Pungoteague Creek on Bayside Eastern Shore of Chesapeake Bay, showing loss of oyster habitat between 1881 (red areas) and 1981 (blue areas).

for seed plantings costs from \$6-30/bushel with the cheaper seed being produced on public oyster grounds and more expensive varieties produced on private leaseholds (\$12 USD/bushel) or hatchery produced (\$15-30 USD/bushel). The price of hatchery produced seed is falling and will likely continue to fall as hatchery capacity and technology is further developed in the Virginia region of the Bay. These repletion efforts in Chesapeake Bay have been analyzed in both Maryland (Cabraal and Wheaton, 1981; Herberich, 2006; Wieland, 2007) and Virginia (Santopietro et al., 2009) from an economic perspective and returns in recent decades for these subsidies have not been positive. This could change if the public ground harvest continues to increase, prices per bushel hold steady or decrease, and the price of shell remains modest compared to a similar volume of harvested live oysters.

The story of this fishery and associated disease impacts in recent decades are similar to the California abalone fishery (Haliotis spp.) where chronic wasting disease completed the decimation of abalone stocks after they were severely overfished (Moore et al., 2002) with water temperature increases (Lafferty and Kuris, 1993) being a driving factor in the initial expression of the disease and subsequent mortality (Chu et al., 1993). Similarly, water temperature increases in the mid-Atlantic have been implicated in oyster disease outbreaks (Soniat et al., 2009,?) as well as extension of oyster diseases northward along the North American coast as waters warm due to climate change (Cook et al., 1998; Hofmann et al., 2001). The disease epidemic plaguing the native oyster in Chesapeake Bay is part of a pattern seen in a wide variety of coastal and marine species in recent decades (Lafferty et al., 2004) and is inhibiting stock recovery of the Chesapeake Bay oyster, though there is evidence (Burke, 2010; Carnegie and Burreson, 2011) that disease mortalities in highsalinity populations of oysters in Virginia waters of Chesapeake Bay are developing resistance. The first Dermo epidemic caused a significant drop in oyster harvests from the public grounds, with a subsequent recovery that peaked at a lower level (Figure 2). This pattern repeats itself with MSX, and appears to be occurring again now with respect to the second Dermo epidemic as the public ground harvest is again showing signs of a significant recovery, although it is clear from this pattern that the overall trend is downward and relates to overfishing over time, with significant disease impacts further suppressing the stocks and harvest. Based on the observed pattern, harvests can be expected to increase further, though they will likely not exceed the numbers recorded prior to the MSX epidemic and remain below 500,000 bushels/year.

\section{RECOMMENDATIONS}

Considering the 1950-59 time period, the only time period in which the repletion program was shown statistically to augment the public oyster fishery, the following actions are suggested for the repletion program today if it continues. Only large scale efforts ( $>500,000$ bushels/shells/year) have a chance at making a significant impact. Repletion, if done, should at least be this 
size annually. Current shell sources are being depleted. New sources of shell need to be identified, both from buried former reefs as well as out-of-state sources, such as mined pre-historic shell from terrestrial deposits in the Gulf of Mexico. Currently, rotational harvest schemes are being used in the Rappahannock River and Tangier/Pocomoke Sound, where in general, a harvest ground is only harvested every other year. It is unknown of this rotational method is helping enhance harvest at present, though a study done several years ago to assess the practice in the Rappahannock River (Santopietro et al., 2009) suggest it is not. Further study of the merits of rotational harvest is recommended. Disease dynamics are shifting to favor oyster survival (Carnegie and Burreson, 2011) and it is possible this rotational management may be helpful now. Studies have assessed the shell budget of reefs in Chesapeake Bay (Mann et al., 2009; Waldbusser et al., 2013) and found that current shell budgets on Chesapeake most of Bay oyster habitat are negative. Shell is being lost faster than it is being replaced, resulting in continuing habitat loss and constant maintenance of extant habitat via shell plantings. The abatement of disease, which is allowing for larger harvests in recent years, will be helpful to reverse this trend as older, larger oysters produce more shell. However, these are the same oysters targeted in the fishery. Additionally, recruitment is historically low in most of the Chesapeake Bay. The few exceptions, in the Great Wicomico, Lynnhaven, and Pianktank Rivers have been the target of large-scale restoration efforts with sanctuary reefs, free from fishing pressure (Schulte and Groth, 2005; Schulte et al., 2009; Chesapeake Bay Foundation, 2010; TNC, 2017) and a single area in the lower James River where oyster stocks have remained higher than all other harvested areas of Chesapeake Bay (Mann et al., 2009). Large-scale sanctuary projects have been demonstrated to increase local recruitment (Schulte and Burke, 2014), this suggests that sanctuaries can play a key role in stock restoration. Stock levels, if high enough, produce enough new shell to maintain and/or build habitat. Sanctuary reefs, appropriately placed and scaled to match the region they are meant to influence can greatly assist in reversing negative trends in stocks and shell budgets. Hydrodynamic models coupled with larval behavior should be used to determine distinct hydrologic units where restoration projects can be placed to influence a river or segment of the Bay. Once the size and local circulation is determined for these units, a properly-sized sanctuary, covering $20-40 \%$ of the historic public ground area in the unit, depending on the degree of larval retention, with areas of lower retention requiring larger sanctuaries than more retentive regions (USACE, 2012) can be built. Sanctuaries can then increase habitat and harvests, as well as ecological services provided by oyster reefs (Kennedy, 1996; Peterson et al., 2003; Coen et al., 2007; Grabowski and Peterson, 2007; Grabowski et al., 2012). While harvested areas can be built with thin layers of shells and reshelled as needed, ideally enough oyster shell would be produced to sustain the habitat if harvest management measures, including rotation, allow enough time for shell accretion once recruitment is enhanced sufficiently. Sanctuaries should be built at higher relief from the bottom, at least $0.2 \mathrm{~m}$ tall, as this has been shown to enhance reef function, (Schulte et al., 2009) though they cost more to build initially than thin-shelled areas. Sanctuaries should also be protected by placing large stones randomly within them, to discourage poaching. The stocks should be better managed, with a fishery-independent survey sufficient to provide the data necessary to put a TAC (total allowable catch) in place for each sub-unit where fishing occurs. Most fishermen are older $(76 \%$ age 40+) (Kirkley, 1997) and it is recommended that a cap on the total number of fishing licenses be put in place to partially restrict access to the fishery. Fishermen in isolated fishing communities, such as on Tangier Island, who are more dependent on fishing for income with fewer (if any) other options, should be preferentially offered licenses as other fishers retire, to help sustain these communities. Overall, though, effort should be made to shift as many fishers as possible to sustainable aquaculture, including cage and rack systems as well as floats, which is where most industry growth is now occurring (Murray and Hudson, 2011; Murray, 2013). Fishers can convert to aquaculture practices either as individuals or by forming co-ops where various tasks are divided up between different fishers, depending on skills. The great majority of the world's oyster production is now via aquaculture (NOAA, 2017), which is sustainable, and this should be encouraged in Chesapeake Bay.

Despite its long history and expectations of its continuance, the data suggests that the Virginia repletion program is neither cost-effective nor a reasonable means to restore the public commons wild oyster fishery (Herberich, 2006; Santopietro et al., 2009) to anything resembling prior levels without massive, ongoing financial commitments and extensive and continual use of dredged shell resources, which are not unlimited. Considering growing public awareness and concerns, culminating an executive order (Obama, 2009) and significant changes in Maryland (TNC, 2010), it is highly unlikely that the large subsidies required will be offered or sustained for any length of time and the future of the fishery will almost certainly be driven primarily by increases in sustainable oyster aquaculture output. Most (95\%) of the world's demand for oysters is now being met by aquaculture (NOAA, 2017) which does not rely on destructive harvest practices on wild oyster reefs but instead reduces the need for such harvests. The Virginian oyster fishery should consider completing the transition from the hunter-gathering phase of oyster production to oyster farming, a far more efficient and less environmentally damaging means of oyster production. The ecology of Chesapeake Bay will be the better for it.

\section{AUTHOR CONTRIBUTIONS}

The author confirms being the sole contributor of this work and approved it for publication.

\section{ACKNOWLEDGMENTS}

This manuscript was greatly improved by the helpful critique and comments of Russell P. Burke and Romauld L. Lipcius. Walter Kloth and Karin Dridge of the US Army Corps provided considerable assistance with the maps. All appropriate permissions have been obtained from the copyright holders for any work reproduced in this manuscript. 


\section{REFERENCES}

Alford, J. T. (1973). The role of management in Chesapeake Oyster production. Geogr. Rev. 63, 44-54. doi: 10.2307/213236

Andrews, J. D. (1964). Oyster mortality studies in Virginia. IV. MSX in James River public seed beds. Proc. Nat. Shellfish Assoc. 53, 65-84.

Andrews, J. D. (1968). Oyster mortality studies in Virginia. VII. Review of epizootiology and origin of Minchinia nelsoni. Proc. Nat. Shellfish Assoc. 58, 23-36.

Andrews, J. D. (1979). Oyster diseases in Chesapeake Bay. Mar. Fish. Rev. 1, 45-53.

Andrews, J. D. (1996). History of Perkinsus marinus, a pathogen of oysters in Chesapeake Bay 1950-1984. J. Shellfish Res. 15, 13-16.

Andrews, J. D., and Wood, J. L. (1967). Oyster mortality studies in Virginia. VI History and distribution of Minchinia nelsoni, a pathogen of oysters, in Virginia. Ches. Sci. 8, 1-13. doi: 10.2307/1350351

Annual Report of the Surgeon General of the Public Health Service (1915). Annual Report of the Surgeon General of the Public Health Service. 1915. Treasury Department; Bureau of the Public Health Service, Washington, DC.

Annual Reports of the Marine Resources Commission (1968-1978). Annual Reports of the Marine Resources Commission. 1968-1982. Richmond, VA.

Auditor of Public Accounts (1776-1928). Receipts and Records of Virginia Oyster Inspectors. Library of Virginia, Richmond, VA.

Bailey, W. (1938). Lime preparation at Jamestown in the Seventeenth Century. William Mary Q. 18, 1-12.

Battle, J. D. (1892). Mobjack Bay Oyster Survey, under Direction if F. Winslow. Oyster Investigations in Chesapeake Bay. United States Commission of Fish and Fisheries; Part XVIII; Report of the Commissioner for the year ending June 30, (1892); Government Printing Office 1894, Washington, DC.

Baylor, J. B. (1893). Rough Sketch of Oyster Rocks, Princess Anne County. Broad Bay, Rainey's Pond, Linkhorn Bay, Long Creek, Lynnhaven River. Rough Sketches of Oyster Rocks. Virginia Auditor of Public Accounts entry no. 118.

Baylor, J. B. (1894). Method of Defining and Locating Natural Oyster Beds, Rocks and Shoals. Oyster Records (pamphlets, one for each Tidewater, VA county, that listed the precise boundaries of the Baylor Survey). Board of Fisheries of Newport News, Virginia.

Baylor, J. B. (1895). Complete Survey of the Natural Oyster Beds, Rocks, and Shoals of Virginia. Report to the Governor of Virginia (1895). Superintendent of Public Documents, Richmond.

Beck, M. W., Brumbaugh, R. D., Airoldi, L., Carranza, A., Coen, L. D., Crawford, C., et al. (2011). Oyster reefs at risk and recommendations for conservation, restoration, and management. Bioscience 61, 107-116. doi: 10.1525/bio.2011.61.2.5

Bosch, D. G., and Shabman, L. A. (1989). The decline of private sector oyster culture in Virginia: causes and remedial policies. Mar. Resour. Econ. 6, 227-243. doi: 10.1086/mre.6.3.42871972

Bradford, G. (1881). Oyster Beds Off the Western Shore of Chesapeake Bay from Smith's Point to New Point Comfort. Map submitted to the Superintendant of the US Coast and Geodetic Survey.

Bratton, J. F., Colman, S. M., Theiler, E. R., and Seal, II. R. R. (2003). Birth of the modern Chesapeake Bay estuary between 7.4 and $8.2 \mathrm{ka}$ and implications for global sea-level rise. Geo Mar. Lett. 22, 188-197. doi: 10.1007/s00367-002-0112-z

Brooks, W. K. (1891). The Oyster. Reprinted in 1996, with Introduction by K. Paynter, Baltimore, MD: The Johns Hopkins University Press.

Brown, O. A. (1872). Oyster-Beds of Chesapeake Bay. Report to the Auditor of Public Accounts of Virginia, Richmond, VA.

Bulletin of the US Fish Commission (1880). Annual reports. 1880-1895. Washington Government Printing Office.

Burke, R. P. (2010). Alternative Substrates as a Native Oyster (Crassostrea virginica) Reef Restoration Strategy in Chesapeake Bay. Dissertation, College of William and Mary; Virginia Institute of Marine Science; Gloucester Point, VA.

Burreson, E. M., and Andrews, J. D. (1988). "Unusual intensification of Chesapeake Bay oysters diseases during recent drought conditions," in Proc Ocean's'88 Conference, ed The Institute of Electrical and Electronics Engineers (Piscataway, NJ: Institute of Electrical and Electronic Engineers, IEEE), 799-802
Burreson, E. M., and Ragone-Calvo, L. (1996). Epizootiology of Perkinsus marinus disease of oysters in Chesapeake Bay, with emphasis on data since 1985. J. Shellfish Res. 15, 17-34.

Burreson, E. M., Stokes, N. A., and Friedman, C. S. (2000). Increased virulence in an introduced pathogen: Haplosporidium nelsoni (MSX) in the eastern oyster Crassostrea virginica. J. Aquat. Anim. Health 12, 1-8. doi: 10.1577/15488667(2000)012\&lt;0001:IVIAIP\&gt;2.0.CO;2

Cabraal, R. A., and Wheaton, F. W. (1981). Production functions for the Maryland Oyster Fishery Trans. Am. Soc. Agric. Eng. 24, 248-251. doi: $10.13031 / 2013.34233$

Carnegie, R. B., and Burreson, E. M. (2011). Declining impact of an introduced pathogen: $H$ aplosoridium nelsoni in the oyster Crassostrea virginica in Chesapeake Bay. Mar. Ecol. Prog. Ser. 432, 1-15. doi: 10.3354/meps09221

Chesapeake Bay Foundation (2010). "On the Brink: Chesapeake's Native Oysters What it Will Take to Bring Them Back.” Annapolis.

Chu, F. L. E., LaPeyre, J. F., and Burreson, E. M. (1993). Perkinsus marinus infection and potential defense-related activities of eastern oysters, Crassostrea virginica: salinity effects. J. Invertebr. Pathol. 62, 226-232. doi: 10.1006/jipa.1993.1104

Coen, L. D., Brumbaugh, R. D., Bushek, D., Grizzle, R., Luckenbach, M. W., Posey, M. H., et al. (2007). Ecosystem services related to oyster restoration. Mar. Ecol. Prog. Ser. 341, 303-307. doi: 10.3354/meps341303

Commission of Fisheries of Virginia (1907-1967). Commission of Fisheries of Virginia. 1907-1967. Annual Reports.

Cook, T., Folli, M., Klinck, J., Ford, S., and Miller, J. (1998). The relationship between increasing sea surface temperature and the northward spread of Perkinsus marinus (Dermo) disease epizootics in oysters. Estuar. Coast. Shelf Sci. 46, 587-597. doi: 10.1006/ecss.1997.0283

Costello, C., Gaines, S. D., and Lynham, J. (2008). Can catch shares prevent fisheries collapse? Science 321, 1678-1681. doi: 10.1126/science.1159478

Daily Press (2005). James River Oysters: An Industry's Rare Catch. Available online at: http://articles.dailypress.com/2005-01-07/news/0501070028_1_jamesriver-oysters-jim-wesson-work-boats. (Accessed May 5, 2015).

de Boer, W. F., Pereria, T., and Guissamulo, A. (2000). Comparing recent and abandoned shell middens to detect the impact of human exploitation on the intertidal ecosystem. Aquat. Ecol. 34, 287-297. doi: 10.1023/A:1009957409421

De Bow, J. D. B. (1858). Oyster trade of the Chesapeake. De Bows Commer. Rev. 24, 259-260.

De Broca, P. (1865). On the Oyster Industries of the United States. Misc. Doc. US Senate, $43^{\text {rd }}$ Congress, $2^{\text {nd }}$ Session, Doc 108; Report of the Commissioner; United States Commission of Fisheries, Part III. 1873-74 and 1874-75.

DeAlteris, J. T. (1988). The geographic development of Wreck Shoal, a subtidal oyster reef of the James River, Virginia. Estuaries 11, 240-249. doi: $10.2307 / 1352010$

Ewart, J. W., and Ford, S. E. (1993). History and Impact of MSX and Dermo Diseases on Oyster Stocks in the Northeast region. Northeast Regional Aquaculture Center, NRAC Fact Sheet No. 200.

Ford, S. E. (1985). Effects of salinity on survival of the MSX parasite Haplosporidium nelsoni (Haskin, Stauber and Mackin) in oysters. J. Shellfish Res. 5, 85-90.

Ford, W. C. (1891). The Writings of George Washington, Vol. XII. New York, NY: G.P. Putnam's Sons; the Knickerbocker Press.

Gardinali, P. R., Sericano, J. L., and Wade, T. L. (2004). Uptake and depuration of toxic halogentated aromatic hydrocarbons by the American oyster (Crassostrea virginica): a field study. Chemosphere 54, 61-70. doi: 10.1016/S0045-6535(03)00754-9

Gascoigne, J., and Lipcius, R. N. (2004). Allee effects in marine systems. Mar. Ecol. Prog. Ser. 269, 49-59. doi: 10.3354/meps269049

Goode, G. B. (1887). The Fisheries and Fishery Industries of the United States. Washington, DC: Government Printing Office.

Grabowski, J. H., and Peterson, C. H. (2007). "Restoring oyster reefs to recover ecosystem services," in Ecosystem Engineers, Plants to Protists, eds K. Cuddington, J. E. Byers, W. G. Wilson, and A. Hastings (Burlington, MA: Elsevier; Academic Press), 281-298.

Grabowski, J. H., Brumbaugh, R. D., Conrad, R. F., Keeler, A. G., Opaluch, J. J., Peterson, C. H., et al. (2012). Economic valuation of ecosystem services provided by oyster reefs. Bioscience 62, 900-909. doi: 10.1525/bio.2012.62.10.10 
Harding, J. M., Mann, R., and Southworth, M. J. (2008). Shell lengthat-age relationships in James River, Virginia, oysters (Crassostrea virginica) collected four centuries apart. J. Shellfish Res. 27, 1109-1115. doi: 10.2983/0730-8000-27.5.1109

Hargis, W. J. Jr., and Haven, D. S. (1999). "Chesapeake oyster bars, their importance, destruction and guidelines for restoring them," in Oyster Bar Habitat Restoration: A Synopsis and Synthesis of Approaches, eds M. W. Luckenbach, R. Mann, and J. A. Wesson (Gloucester Point, VA: Virginia Institute of Marine Science Press), 329-358.

Haven, D. S., Hargis, W. J. Jr., and Kendall, P. C. (1978). The Oyster Industry of Virginia: Its Status, Problems and Promise. A Comprehensive Study of the Oyster Industry in Virginia. Special Papers in Marine Science No. 4 of the Virginia Institute of Marine Science, 1024.

Haven, D. S., Whitcomb, J. P., and Kendall, P. C. (1981). The Present and Potential Productivity of the Baylor Grounds in Virginia. Special Report in Applied Marine Science and Ocean Engineering No. 243; Virginia Institute of Marine Science, Gloucester Point, VA 23062.

Herberich, D. (2006). Estimated Return to Harvest due to the Maryland Department of Natural Resources Repletion Activities 1990-2006.

Hobbs, C. (2004). Geological history of Chesapeake Bay, USA. Quat. Sci. Rev. 23, 641-661. doi: 10.1016/j.quascirev.2003.08.003

Hofmann, E. E., Ford, S. E., Powell, E. N., and Klinck, J. M. (2001). Modeling studies of the effect of climate variability on MSX disease in Eastern Oyster (Crassostrea virginica) populations. Hydrobiologia 460, 195-212. doi: 10.1023/A:1013159329598

Ingersoll, E. (1881). "The oyster industry," in The History and Present Condition of the Fishery Industries, ed G. Brown Goode (Washington, DC: U.S. Gov. Print. Off), 251.

Jagani, S. (2011). Prehistoric Anthropogenic Change in Coastal Ecosystems: Human Impacts on the Chesapeake Bay Oyster Fishery. Thesis, University of California, Berkeley, CA.

Jarvis, N. D. (1988). Curing and canning of fishery products: a history. Mar. Fish. Rev. 50, 180-185.

Jordan, S. J., and Coakley, J. M. (2004). Long-term projections of eastern oyster populations under various management scenarios. J. Shellfish Res. 23, 63-72. doi: 10.2983/0730-8000(2008)27[729:LTIOPD]2.0.CO;2

Keiner, C. (2009). The Oyster Question: Scientists, Watermen and the Maryland Chesapeake Bay Since 1880. University of Georgia Press, Georgia,GA.

Kellum, T. (2008). Written Testimony to the U.S. House of Representatives Committee on Natural Resources Subcommittee on Fisheries, Wildlife, and Oceans: Oversight Hearings on Past, Current, and Future Efforts to Restore Oysters in the Chesapeake Bay.

Kennedy, V. S. (1996). The ecological role of the eastern oyster, Crassostrea virginica, with remarks on disease. J. Shellfish Res. 15, 177-183.

Kennedy, V. S., and Breisch, L. L. (1983). Sixteen decades of political management of the oyster fishery in Maryland's Chesapeake Bay J. Environ. Manage. 16, 153-171.

Kent, B. W. (1988). Making Dead Oysters Talk: Techniques for Analyzing Oysters from Archaeological Sites. Annapolis, MD: Maryland Historical Trust, 107.

Kirby, M. X. (2004). Fishing down the coast: historical expansion and collapse of oyster fisheries along continental margins. Proc. Natl. Acad. Sci.U.S.A. 101, 13096-13099. doi: 10.1073/pnas.0405150101

Kirkley, J. (1997). Virginia's Commercial Fishing Industry. Available online at: http://web.vims.edu/library/Kirkley/Kirkley2.pdf (Accessed June 3, 2015).

Lafferty, K. D., and Kuris, A. M. (1993). Mass mortality of abalone, Haliotis cracherodii, on the California Channel Islands: tests of epidemiological hypotheses. Mar. Ecol. Progr. Ser. 96, 239-248. doi: 10.3354/meps096239

Lafferty, K. D., Porter, J. W., and Ford, S. E. (2004). Are diseases increasing in the ocean? Annu. Rev. Ecol. Evol. Syst. 35, 31-54. doi: 10.1146/annurev.ecolsys.35.021103.105704

Lebergott, S. (2017). Wages and Working Conditions, by Stanley Lebergott, Website: Econlib.org, Available online at: http://www.econlib.org/library/Enc1/ WagesandWorkingConditions.html. (Accessed March 22, 2016).

Lenihan, H. S. (1999). Physical-biological coupling on oyster reefs: how habitat structure influences individual performance. Ecol. Monogr. 69, 251-275.

Lenihan, H. S., and Peterson, C. H. (1998). How habitat degradation through fishery disturbance enhances impacts of hypoxia on oyster bars. Ecol. Appl. 8, 128-140. doi: 10.1890/1051-0761(1998)008[0128:HHDTFD]2.0.CO;2
Lenihan, H. S., and Peterson, C. H. (2004). Conserving oyster reef habitat by switching from dredging and tonging to diver-harvesting. Fish. Bull. 102, 298-305.

Lynch, M. P. (2005). "An unprecedented scientific community response to an unprecedented event: tropical storm Agnes and the Chesapeake Bay," in Hurricane Isabel in Perspective. Chesapeake Research Consortium ed K. G. Sellner (Edgewater, MD: CRC Publication), 5-160.

Mackenzie, C. L. (1996). History of oystering in the United States and Canada, featuring the eight greatest oyster estuaries. Mar. Fish. Rev. 58, 1-78.

Mackenzie, C. L. (2007). Causes underlying the historical decline in Eastern oyster (Crassostrea virginica Gmelin, 1791) landings. J. Shellfish Res. 26, 927-938. doi: 10.2983/0730-8000(2007)26[927:CUTHDI]2.0.CO;2

Mann, R. M., Harding, J. M., and Southworth, M. (2009). Reconstructing precolonial oyster demographics in the Chesapeake Bay, USA. Estuar. Coast. Shelf Sci. 85, 217-222. doi: 10.1016/j.ecss.2009.08.004

McCormick-Ray, M. G. (1998). Oyster bars in 1878 seascape pattern-Winslow revisited. Estuaries 21, 784-800. doi: 10.2307/1353281

McCormick-Ray, M. G. (2005). Historical oyster reef connections to Chesapeake Bay - a framework for consideration. Estuar. Coas. Shelf Sci. 64, 119-134. doi: 10.1016/j.ecss.2005.02.011

McHugh, J. L., and Bailey, R. S. (1957). History of Virginia's commercial fisheries - neglected historical records throw light on today's problems. Virginia J. Sci. $8,42-64$.

Moore, H. F. (1910). Condition and Extent of Oyster Beds of James River, Virginia. US Bureau of Fisheries Document No. 729, US Government Printing Office, Washington, DC

Moore, J. D., Finley, C. A., Robbins, T. T., and Friedman, C. S. (2002). Withering syndrome and restoration of Southern California abalone populations. CalCOFI Rep. 43, 112-117.

Moore, J. T. (1982). Gunfire on the Chesapeake, Governor Cameron and the oyster pirates, 1882-1885. Virginia Magaz. Hist. Biogr. 90, 367-377.

Murray, T. J. (2013). Virginia Shellfish Aquaculture Situation and Outlook Report: Results of 2012 Virginia Shellfish Aquaculture Crop Reporting Survey. Virginia Sea Grant Marine Extension Program; Virginia Institute of Marine Science; Gloucester Point VA.

Murray, T. J., and Hudson, K. (2011). Virginia Shellfish Aquaculture Situation and Outlook Report: Results of 2010 Virginia Shellfish Aquaculture Crop Reporting Survey. Virginia Sea Grant Marine Extension Program; Virginia Institute of Marine Science, Gloucester Point VA.

Murray, T. J., and Kirkley, J. E. (2010). Estimated Economic Impact of Gulf Oil Spill On. Virginia Institute of Marine Science College of William \& Mary Gloucester Point, Virginia VIMS Marine Resource Report No. 2010-7.

Nappier, S. P., Graczyk, T. C., and Schwab, K. J. (2008). Bioaccumulation, retention, and depuration of enteric viruses by Crassostrea virginica and Crassostrea ariakensis oysters. Appl. Environ. Microbiol. 74, 6825-6831. doi: 10.1128/AEM.01000-08

National Academy of Sciences (2004). Nonnative Oysters in Chesapeake Bay, 344.

NOAA (2017). From Farm to Your Table, Oysters Offer a Sustainable Choice. Available online at: http://www.westcoast.fisheries.noaa.gov/stories/2016/26_ 08262016_sustainable_oyster_farming.html. (Accessed January 5, 2017).

Obama, B. H. (2009). Executive Order 13508. Chesapeake Bay Protection and Restoration.

Paxton, J. G. (1858). Speech of James G. Paxton Esq. of Rockbridge, Relative to the Oyster Funding of Virginia. Delivered in the House of Delegates of Virginia. Richmond, VA: Printed by Ritchie and Dunnavant.

Peterson, C. H., Grabowski, J. H., and Powers, S. P. (2003). Estimated enhancement of fish production resulting from restoring oyster reef habitat: quantitative valuation. Mar. Ecol. Prog. Ser. 264, 249-264. doi: 10.3354/meps2 64249

Piketty, T., and Saez, E. (2003). Income inequality in the United States, 1913-1998. Quart. J. Econ. 118, 1-39. doi: 10.1162/00335530360535135

Poorter, L., Bongers, F., Sterck, F. J., and Wöll, H. (2003). Architecture of 53 rain forest tree species differing in adult stature and shade tolerance. Ecology 84, 602-608. doi: 10.1890/0012-9658(2003)084[0602:AORFTS]2.0.CO;2

Ragone Calvo, L. M., Dungan, C. F., Roberson, B. S., and Burreson, E. M. (2003). A systematic evaluation of factors controlling Perkinsus marinus transmission dynamics in the lower Chesapeake Bay. Dis. Aquat. Organ. 56:75-86. doi: 10.3354/dao056075 
Ragone, L. M., and Burreson, E. M. (1993). Effect of salinity on Infection progression and pathogenicity of Perkinsus marinus in the eastern oyster, Crassostrea virginica (Gmelin). J. Shellfish Res. 12, 1-7.

Reboucas do Amaral, M., de Freitas-Rebelo, C. M., Machado-Torres, J. P., and Pfeiffer, W. C. (2005). Bioaccumulation and depuration of $\mathrm{Zn}$ and $\mathrm{Cd}$ in mangrove oysters (Crassostrea rhizophorae, Guilding, 1928) transplanted to and from a contaminated coastal lagoon. Mar. Environ. Res. 59, 277-285. doi: 10.1016/j.marenvres.2004.05.004

Report $1736,87^{\text {th }}$ Congress. (1962). Rehabilitation of Oyster Beds. USCongress, Washington, DC.

Report of the Board of Fisheries to the Governor of Virginia (1900-1907). Report of the Board of Fisheries to the Governor of Virginia. Series of Reports, report year irregular, (1900-1907) Richmond, VA.

Report of the Commission of Fisheries of Virginia. 1907-1967 (1907-1980). Report of the Commission of Fisheries of Virginia. 1907-1967. Commonwealth of Virginia; Office of the Commission of Fisheries, Richmond, VA.

Report of the Virginia Fisheries Laboratory (1949-1959). Virginia Fisheries Laboratory, 1953, Virginia Fisheries Laboratory, 1955, Virginia Fisheries Laboratory $(1951,1953,1955,1957,1959)$. Report of the Virginia Fisheries Laboratory. Biennial Reports. 1951, 1953, 1955, 1957, 1959. Virginia Fisheries Laboratory, Gloucester, VA.

Rick, T. C., Reeder-Myers, L. A., Hofman, C. A., Breitburg, D., Lockwood, R., Henkes, G., et al. (2016). Millennial-scale sustainability of the Chesapeake Bay Native American oyster fishery. Proc. Natl. Acad. Sci. U.S.A. 113, 6568-6573. doi: $10.1073 /$ pnas. 1600019113

Rothschild, B. J., Ault, J. S., Goulletquer, P., and Heral, M. (1994). Decline of the Chesapeake Bay oyster population: a century of habitat destruction and overfishing. Mar. Ecol. Prog. Ser. 111, 29-39. doi: 10.3354/meps1 11029

Ryder, J. A. (1884). "The life history of the Oyster," in The Fisheries and Fishery Industries of the United States, ed G. B Goode (Washington, DC: Washington Government Printing Office 1884), 711-756

Santopietro, G. D., Stephenson, K., Satyal, V. A., and Wesson, J. (2009). A bioeconomic analysis of management plans for the public oyster grounds of the Rappahannock River. J. Shellfish Res. 28, 235-241. doi: 10.2983/035. 028.0205

Schulte, D. M., and Burke, R. P. (2014). Recruitment enhancement as an indicator of oyster restoration success in Chesapeake Bay. Ecol. Restor. 32, 434-440. doi: $10.3368 /$ er.32.4.434

Schulte, D. M., and Groth, K. A. (2005). Lynnhaven River Oyster Restoration Plan. US Army Corps of Engineers.

Schulte, D. M., Burke, R. P., and Lipcius, R. N. (2009). Unprecedented restoration of a native oyster metapopulation. Science 325, 1124-1128. doi: $10.1126 /$ science. 1176516

Shabman, L., and Capps, O. (1984). Demand for Chesapeake Bay Oysters. An Evaluation of Alternative Strategies for Virginia Oyster Grounds Management: Economic Considerations in Policy Design. Virginia Polytechnic Institute and State University. VSG-88-03.

Smith, G. F., Bruce, D. G., Roach, E. B., Hansen, A., Newell, R. I. E., and McManus, A. M. (2005). Assessment of recent habitat conditions of eastern oyster Crassostrea virginica bars in mesohaline Chesapeake Bay. North Am. J. Fish. Manage. 25, 1569-1590. doi: 10.1577/M04-058.1

Smith, G. F., Roach, E. B., and Bruce, D. G. (2003). The location, composition, and origin of oyster bars in mesohaline Chesapeake Bay. Estuar. Coast. Shelf Sci. 56, 391-409. doi: 10.1016/S0272-7714(02)00191-9

Soniat, T. M., Hofmann, E. E., Klinck, J. M., and Powell, E. N. (2009). Differential modulation of eastern oyster (Crassostrea virginica) disease parasites by the ElNino-Southern Oscillation and the North Atlantic Oscillation. Int. J. Earth Sci. 98, 99.

Soniat, T. M., Hofmann, E. E., Klinck, J. M., and Powell, E. N. (2009). Differential modulation of eastern oyster (Crassostrea virginica) disease parasites by the ElNino-Southern Oscillation and the North Atlantic Oscillation. Int. J. Earth Sci. 98, 99-114. doi: 10.1007/s00531-008-0364-6

Sumaila, U. R., Cisneros-Montemayor, A. M., Dyck, A. A., Huang, L. L., Cheung, W., Jacquet, J., et al. (2012). Impact of the Deepwater Horizon well blowout on the economics of US Gulf fisheries. Can. J. Fish. Aquat. Sci. 69, 499-510. doi: 10.1139/f2011-171

Tarnowski, M. (2004). Evaluation of the Effects of Power Dredging for Oysters. Maryland Department of Natural Resources.
The Alexandria Gazette (1963-1964). The Alexandria Gazette, May 29, 1863, September 21, 1863, September 24, 1863, October 5, 1863, October 12, 1863, December 29, 1863 and January 21, 1864.

Tice, J. T. (1982). Gunfire on the Chesapeake: Governor Cameron and the oyster pirates, 1882-1885. Virginia Magaz. Hist. Biogr. 90, 367-377.

TNC, The Nature Conservancy (2010). Available online at: http://www.nature.org/ ourinitiatives/regions/northamerica/unitedstates/maryland_dc/newsroom/ cbf-and-tnc-applaud-new-maryland-oyster-recovery-plan.xml

TNC, The Nature Conservancy (2017). Piankatank Oyster Restoration. Available online at: http://www.chesapeakebay.net/channel_files/21643/update_tnc_ piankatank_oyster_restoration.pdf). (Accessed Jan 8, 2017).

Tyndall, R. (1608). Chart of the James and York Rivers. Available online at: http://www.she-philosopher.com/gallery/1608Tindall.html.

U.S Army Corps of Engineers (2012). Available online at: http://www.nab.usace. army.mil/Missions/Environmental/Oyster-Restoration/Oyster-Master-Plan,/ (Accessed June 8, 2015).

U.S Census $(1850,1860)$. Statistical View of the United States, Compendium of the Seventh and Eigth Census. Washington DC,

Valderrama, D., Anderson, J. L., Rashid, S. U., Munro, G. R., and Sutinen, J. G. (2007). Improving utilization of the Atlantic sea scallop resource: an analysis of rotational management of fishing grounds. Land Econ. 83, 86-103. doi: $10.3368 / \mathrm{le} .83 .1 .86$

Virginia Auditor of Public Accounts (1776-1928). Library of Virginia. Richmond, VA.

Virginia Marine Resources Commission (1978-2012). Meeting Minutes. Available online at: http://www.mrc.virginia.gov/ (Accessed July 9, 2015).

Waldbusser, G. G., Powell, E. N., and Mann, R. (2013). Ecosystem effects of shell aggregations and cycling in coastal waters: an example of Chesapeake Bay oyster reefs. Ecology 94, 895-903. doi: 10.1890/12-1179.1

Wennersten, J. R. (1981). The Oyster Wars of Chesapeake Bay. Centerville, MD: Tidewater Publishers.

Wieland, R. C. (2007). Managing Oyster Harvests in Maryland's Chesapeake Bay. Final Programmatic Environmental Impact Statement for Oyster Restoration in Chesapeake Bay Including the Use of a Native and/or Nonnative Oyster. U.S. Army Corps of Engineers, Norfolk, VA.

Wilberg, M. J., Livings, M. E., Barkman, J. S., Morris, B. T., and Robinson, J. M. (2011). Overfishing, disease, habitat loss, and potential extirpation of oysters in upper Chesapeake Bay. Mar. Ecol. Prog. Ser. 436, 131-144. doi: 10.3354/meps09161

Winslow, F. (1881). Deterioration of American Oyster Beds. Popul. Sci. Monthly 20, 29-42.

Winslow, F. (1882). Report on the Oyster Beds of the James River, VA., and of Tangier and Pocomoke Sounds, Maryland and Virginia. US Coast, and Geodetic Survey Report for 1881, 1-87.

Withington, C. F. (1965). Virginia Minerals. Large-Scale Production from Hampton Roads. Division of Mineral Resources; Commonwealth of Virginia Department of Conservation and Economic Development.

Woods, H., Hargis, W. J. Jr, Hershner, C. H., and Mason, P. (2005). Disappearance of the natural emergent 3-dimensional oyster reef system of the James River, Virginia, 1871-1948. J. Shellfish Res. 24, 139-142. doi: 10.2983/07308000(2005)24[139:DOTNED]2.0.CO;2

Woods, H., Hargis, W. J. Jr., Hershner, C. H., and Mason, P. (2004). Improving Siting and Construction Criteria for Oyster Bar Restoration. VIMS Special Report in Applied Marine Science and Ocean Engineering (SRAMSOE) \#387. Virginia Institute of Marine Science, Gloucester Point, VA.

Worm, B., Barbier, E. B., Beaumont, N., Duffy, J. E., Folke, C., Hapern, B. S., et al. (2006). Impacts on biodiversity loss on ocean ecosystem services. Science 314, 787-790. doi: $10.1126 /$ science.1132294

Conflict of Interest Statement: The author declares that the research was conducted in the absence of any commercial or financial relationships that could be construed as a potential conflict of interest.

Copyright (๑) 2017 Schulte. This is an open-access article distributed under the terms of the Creative Commons Attribution License (CC BY). The use, distribution or reproduction in other forums is permitted, provided the original author(s) or licensor are credited and that the original publication in this journal is cited, in accordance with accepted academic practice. No use, distribution or reproduction is permitted which does not comply with these terms. 